УДК 551.77(571.1)

\author{
ПАЛИНОСТРАТИГРАФИЯ И ГЕНЕЗИС ВЕРХНЕМЕЛОВЫХ \\ И КАЙНОЗОЙСКИХ ОТЛОЖЕНИЙ ЮЖНОЙ ЧАСТИ \\ КУЛУНДИНСКОЙ ВПАДИНЫ, АЛТАЙСКИЙ КРАЙ \\ (C) 2019 г. Н. К. Лебедева ${ }^{1,2, *}$, О. Б. Кузьмина ${ }^{1,2}$, И. В. Хазина ${ }^{1}$, \\ Г. Г. Русанов ${ }^{3}$, Л. А. Глинских ${ }^{1}$ \\ ${ }^{1}$ Институт нефтегазовой геологии и геофизики им. А.А. Трофимука СО РАН, Новосибирск \\ ${ }^{2}$ Новосибирский государственный университет, Новосибирск \\ ${ }^{3}$ Отдельное структурное подразделение “Горно-Алтайская экспедиция” Акционерного общества \\ “Сибирское производственно-геологическое объединение”, \\ 659370, Алтайский край, Малоенисейское, ул. Советская, 15, Россия \\ *e-mail: LebedevaNK@ipgg.sbras.ru
}

Поступила в редакцию 01.03.2018 г.

Получена после доработки 31.05.2018 г.

Принята к публикации 25.10.2018 г.

\begin{abstract}
Представлены результаты палинологического и микропалеонтологического изучения верхнемеловых-кайнозойских толщ, вскрытых скважинами 23 и 19 Алейской площади (Алтайский край). Полученные данные позволили обосновать возраст отложений, высказать предположения об условиях их формирования, уточнить расчленение разреза на свиты. В меловой части разреза скв. 23 установлены два палинокомплекса: первый характеризует леньковскую свиту и датируется сеноманом-туроном; второй выявлен в верхнесымской подсвите и датируется маастрихтом. На верхнемеловых отложениях залегает палеогеновая островновская свита континентального генезиса. В скв. 19 и 23 эта свита содержит спорово-пыльцевые спектры предположительно позднепалеоценового-раннеэоценового и среднеэоценового возраста соответственно. По палинологическим данным обоснован позднемиоценовый возраст отложений верхней части разреза скв. 23 и их принадлежность к павлодарской свите. Структура палинологических комплексов, особенности мацерата, отсутствие фораминифер указывают на континентальный генезис верхнемеловых-палеогеновых отложений, распространенных в южной части Кулундинской впадины Алтайского края.
\end{abstract}

Ключевые слова: биостратиграфия, верхний мел, палеоген, неоген, Кулундинская впадина, юг Западной Сибири, Алтайский край, палинология, наземные палиноморфы

DOI: https://doi.org/10.31857/S0869-592X27655-77

\section{ВВЕДЕНИЕ}

Мел-палеоген-неогеновые отложения Алтайского края весьма слабо изучены. Основные материалы по стратиграфии, условиям формирования и залегания этих толщ опубликованы в крупных сводках (Адаменко, 1974; Новиков, 2004; Русанов, 2009). Однако остается много нерешенных вопросов, и любые новые данные, в том числе полученные по немногочисленным глубоким скважинам, вносят важный вклад в понимание геологического строения надпалеозойского чехла в этом регионе. В этой связи публикация В.М. Подобиной с соавторами (2011) по стратиграфии верхнемеловых и палеогеновых отложений, вскрытых тремя скважинами на Алейской площади, привлекла внимание специалистов. Авторы упомянутой статьи провели ми- крофаунистическое, карпологическое и палинологическое изучение 20 образцов, на основании которого впервые для юга Кулундинской впадины сделали заключение о наличии морских отложений мела и палеогена в скважинах 15, 19, 23. Как следствие, граница максимума морской меловой и палеогеновой трансгрессии была передвинута более чем на 50 км к югу (Подобина и др., 2011) (рис. 1). Появившиеся позднее палеомагнитные данные по скв. 19, 23 (Гнибиденко и др., 2017) опирались на стратиграфические построения, предложенные Подобиной и др. (2011).

Авторами настоящей статьи был повторно опробован и изучен керн скважин 23 и 19 Алейской площади. На основании детального палинологического и микрофаунистического анализа были получены возрастные оценки мел- 
палеогеновых осадков на изученной территории и сделаны выводы об условиях их формирования и строении, существенно отличающие от предшествующих результатов.

\section{МАТЕРИАЛ И МЕТОДЫ}

Материалом для палинологического исследования послужили 88 образцов из скв. Алейская 23, отобранных из мел-неогеновых отложений в интервале 384.5-77.5 м, а также 5 образцов из мелпалеогеновых отложений скв. Алейская 19. На микрофаунистический анализ были отобраны 50 образцов из инт. 364.7-192.7 м в скв. Алейская 23.

Скважины 23 и 19 Алейской площади пробурены в юго-восточной части Кулундинской впадины (Гусев и др., 2015) в пределах Барнаульской структурной ступени (террасы), выделенной О.М. Адаменко (1974, 1976) (рис. 1). Литологическое расчленение и описание, а также каротажные диаграммы изученной скв. Алейская 23 (мел-эоцен) приводятся на рис. 2. Некоторые несовпадения данных каротажа и литологической колонки, построенной на основании описания керна, объясняются не очень высоким выходом керна, составляющим практически по всему разрезу от 40 до $65 \%$.

Палинологический анализ. Образцы для палинологического анализа обрабатывали по химической методике, принятой в Лаборатории палеонтологии и стратиграфии мезозоя и кайнозоя Института нефтегазовой геологии и геофизики им. А.А. Трофимука СО РАН, Новосибирск (Лебедева и др., 2013). Микрофотографирование проводили в постоянных препаратах, изготовленных на желатин-глицериновой основе, с помощью микроскопа ZEISS Axioskop 40, снабженного фотокамерой Canon PowerShot G10. В каждом спорово-пыльцевом спектре (если возможно) подсчитывали не менее 200-300 зерен палиноморф. При подсчете процентного содержания таксонов за 100\% принималась сумма всех микрофитофоссилий, которые были представлены спорами, пыльцой наземных растений, пресноводным микрофитопланктоном, спорами грибов. Сохранность палиноморф была хорошая и очень хорошая. Однако в некоторых образцах растительные микрофоссилии отсутствовали.

Коллекция палинологических препаратов хранится в Лаборатории палеонтологии и стратиграфии мезозоя и кайнозоя Института нефтегазовой геологии и геофизики им. А.А. Трофимука СО РАН (Новосибирск).

Микрофаунистический анализ. Обработку образцов для микрофаунистического анализа производили по стандартной методике (Основы..., 1960). Относительно рыхлые разности пород (образцы навеской 200 г) отмачивали в воде в течение 1-2 недель, а затем дезинтегрировали простым кипячением в течение нескольких часов. Более твердые породы разрушали с помощью многократной заморозки в морозильной камере или с использованием расплава гипосульфита натрия, с последующим кипячением. После этого осадок отмывали в проточной воде через сито диаметром ячеи 56 мкм и сушили. Высушенный осадок изучали под стереомикроскопом Carl Zeiss Stemi 2000-С.

Все образцы скв. Алейская 23 были исследованы на микрофауну, однако ни в одном их них фораминиферы не были обнаружены.

\section{КРАТКИЕ СВЕДЕНИЯ ПО СТРАТИГРАФИИ МЕЛ-КАЙНОЗОЙСКИХ ОТЛОЖЕНИЙ КУЛУНДИНСКОЙ ВПАДИНЫ}

Меловые и палеогеновые отложения развиты в пределах Центрально-Кулундинской, Барнаульской и Бийской структурных террас Кулундинской впадины (Адаменко, 1974, 1976), которые отличаются по составу и мощности рыхлых осадков, слагающих эти террасы. Апттуронская леньковская свита развита только в центре Кулундинской впадины, а на остальной ее части либо отсутствует, либо заполняет локальные изолированные западины в рельефе фундамента. В северном направлении она замещается покурской свитой (Адаменко, 1974). Морские верхнемеловые осадки ипатовской, славгородской и ганькинской свит распространены только на территории ЦентральноКулундинской террасы. Континентальный аналог этих отложений - сымская свита - развит на территории Барнаульской и отчасти Бийской структурных террас (Адаменко, 1974).

Палеогеновая островновская свита выделяется на юге Кулундинской впадины (Зальцман, 1968; Унифицированные..., 2001), ее стратотипом является разрез скв. 373 (с. Мамонтово), расположенной несколько севернее, чем скв. Алейская 23. В стратотипе эта свита залегает на верхнемеловой сымской свите и перекрывается нижнеолигоценовой атлымской свитой. Островновская свита сложена серыми, светлосерыми до белых, темно-серыми, иногда красновато-зеленовато-серыми каолиновыми глинами и алевритами, содержащими прослои песков и галечников, а также бурых углей; ее мощность 35-40 м (Зальцман, 1968; Адаменко, 1974). Отложения вскрываются скважинами на глубине более 200 м; предполагается, что они выполняют погребенные долины (Адаменко, 1974). Согласно палинологическим данным (Адаменко, 1974), возрастной диапазон свиты охватывает весь палеоцен и эоцен, что отражено в региональной стратиграфической схеме (Унифицированные..., 


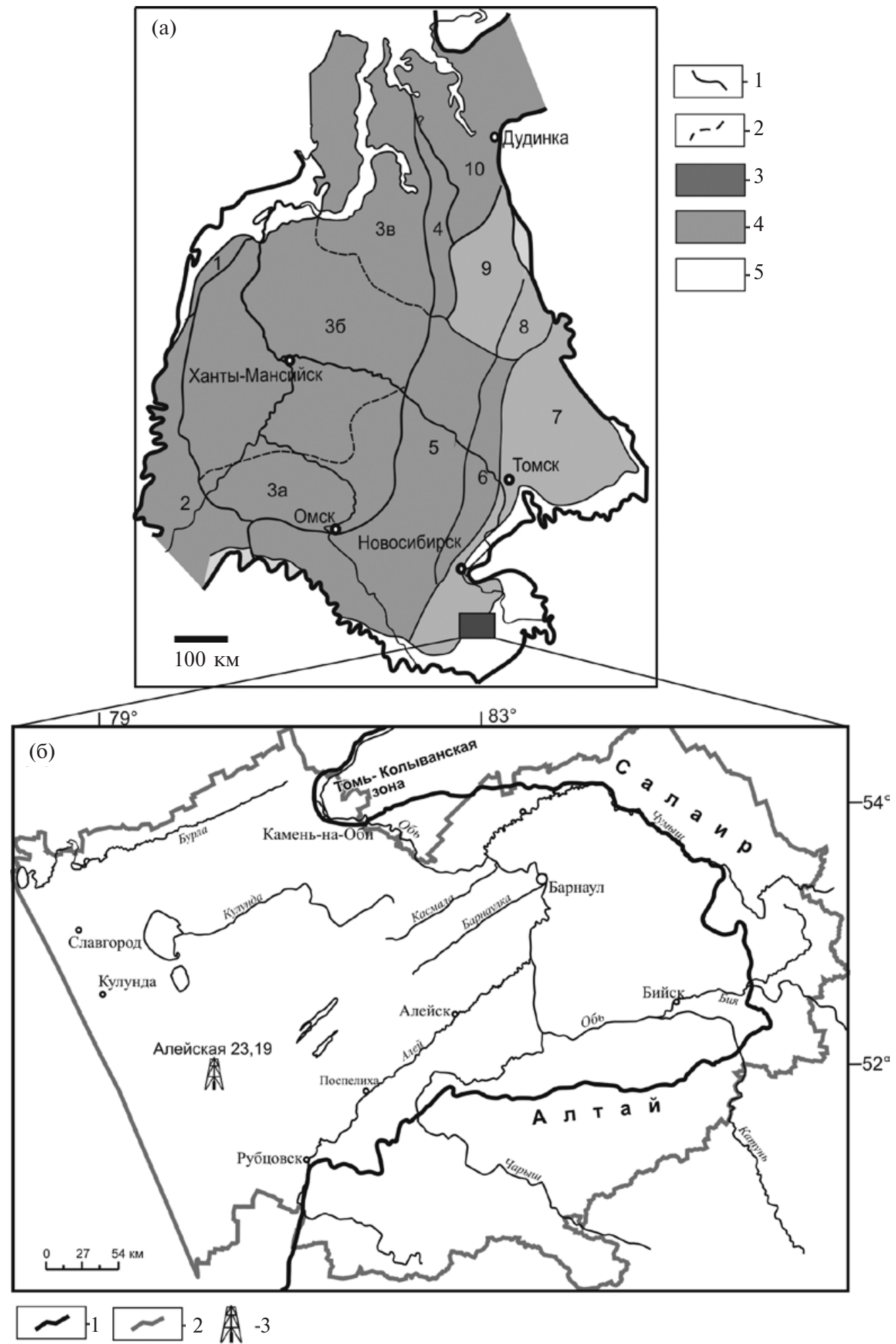

Рис. 1. Местоположение изучаемого района на схеме фациального районирования Западной Сибири для верхнего мела (а) и положение скважин 23 и 19 Алейской площади (б).

(a): 1, 2 - границы фациальных районов (1) и подрайонов (2); 3 - морские отложения; 4 - континентальные отложения; 5 - зоны отсутствия отложений. Фациальные районы и подрайоны: 1 - Полярное и Приполярное Зауралье; 2 - Северное, Среднее и Южное Зауралье; 3 - Ямало-Тюменский район: За - Тюменско-Васюганский подрайон, $3 б$ - Березово-Вартовский подрайон, Зв - Ямало-Уренгойский подрайон; 4 - Тазовский район; 5 Омско-Ларьякский район; 6 - Колпашевский район; 7 - Кулундино-Чулымский район; 8 - Елогуйский район; 9 - Туруханский район; $10-$ Усть-Енисейский район.

(б): 1 - граница Западной Сибири; 2 - административная граница Алтайского края; 3 - местоположение скважин. 


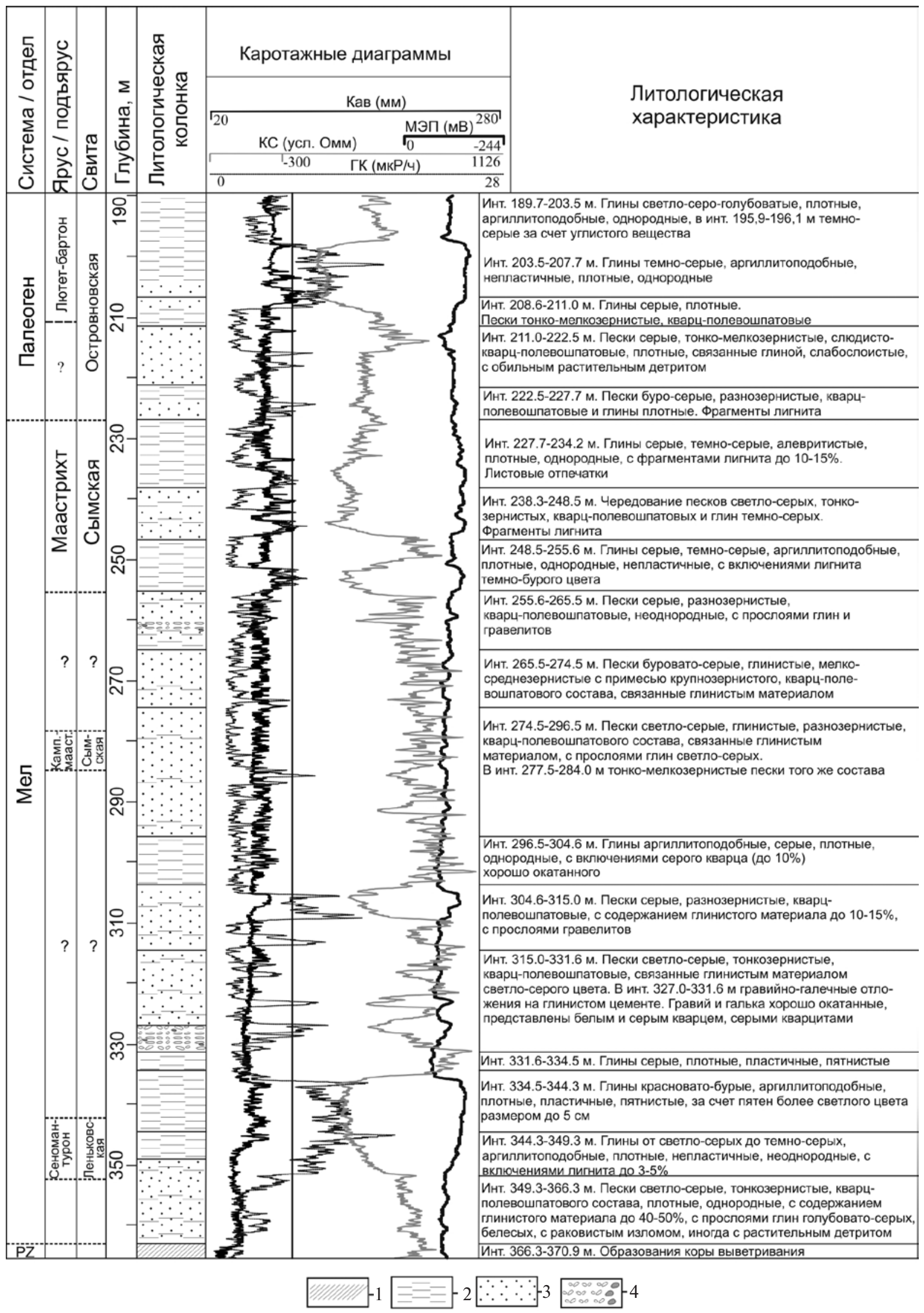

Рис. 2. Разрез скважины Алейская 23, его литологическое описание и каротажные диаграммы.

1 - кора выветривания по палеозойским породам; 2 - глины; 3 - пески; 4 - гравелиты. Сокращения: Камп.мааст. - Кампан-маастрихт. 
2001). Морские отложения палеоценового возраста (талицкая свита) установлены только на севере Кулундинской впадины (Зальцман, 1968), тогда как морской эоцен (люлинворская и тавдинская свиты) развиты только на территории Центрально-Кулундинской структурной террасы (Адаменко, 1974).

Островновская свита в исследуемом нами районе несогласно перекрывается континентальными отложениями олигоцена - атлымской, новомихайловской свитами, а также крутихинской свитой, верхняя часть которой относится уже к нижнему миоцену. Выше по разрезу залегают рубцовская (средний-верхний миоцен), павлодарская (верхний миоцен) свиты и четвертичные отложения.

\section{ПАЛИНОСТРАТИГРАФИЯ}

\section{Скважина Алейская 23}

В мел-палеогеновых и неогеновых отложениях, вскрытых скв. Алейская 23, на основании изменений в составе спор и пыльцы наземных растений установлено пять биостратонов в ранге слоев с палинокомплексами (ПК). Распределение пыльцы и спор, а также непыльцевых палиноморф в разрезе скв. Алейская 23 приведено на рис. $3,4$.

Образцы 1-11 практически не содержат микрофитофоссилии, за исключением редких зерен Taxodiaceaepollenites, Coniferales gen. indet., Tricolpites.

Слои с ПК 1 Schizaeaceae, Taurocusporites reduncus, Tricolpites (нижний инт. 349.2-353.7 м, верхний инт. 340-343.5 м; обр. 12-19), леньковская свита.

Содержание спор мхов и папоротникообразных составляет 12-45\%, пыльцы голосеменных 5-18\%, пыльцы покрытосеменных - 40-80\%.

Среди спор мхов и папоротникообразных преобладают Leiotriletes spp., Osmundacidites sp., Cyathidites sp. Многочисленны и разнообразны представители семейства Schizaeaceae: Appendicisporites matesovae (Bolch.) Nor., A. unicus (Markova) Singh, A. tricornitatus Weyl. et Gruf., A. macrorhyzus (Mal.) Bond., A. bilateralis Singh, A. problematicus (Burger) Singh, A. erdtmanii (Poc.) Singh, Appendicisporites spp., Cicatricosisporites hughesi Dett., C. annulatus Arch. et Gam., C. auritus Singh, C. pacificus (Bolch.) Chlon., C. augustus Singh, C. pseudotripartitus (Bolch.) Dett., Cicatricosisporites spp., Klukisporites variegatus Coup., Klukisporites sp. Присутствуют: Rouseisporites reticulatus Poc., Crybelosporites sp., Foveosporites sp., Costatoperforosporites fistulosus Deak, Aequitriradites spinulosus (Cook. et Dett.) Cook. et Dett., A. verrucosus Cook. et Dett., Concavissimisporites punctatus (Delc. et Sprum.) Bren., Laevigatosporites ovatus Wils. et Web., Biretisporites sp., Lycopodiumsporites sp., Gleicheniidites spp., Eboraciasporites sp., Stereisporites spp., Matonisporites sp., Distaltriangulisporites perplexus (Singh) Singh, Taurocusporites reduncus (Bolch.) Stover, Coptospora sp., Plicatella crimensis (Bolch.) Dorh., Camarozonosporites insignis Nor. и др. (табл. I).

В составе пыльцы голосеменных доминирует двухмешковая пыльца хвойных Coniferales gen. indet., Pinuspollenites spp., присутствует пыльца Alisporites spp., Cedripites spp., Podocarpidites spp., Phyllocladidites sp., Taxodiaceaepollenites sp., Araucariacites sp., Sequoiapollenites sp.

B составе палинокомплекса доминирует пыльца покрытосеменных рода Tricolpites, присутствует Retitricolpites.

Особенности состава описанного комплекса характерны для сеноман-туронских комплексов (СПК VII /5/-СПК VIII /3/; Решение..., 1991), хорошо изученных на территории Западной Сибири. Обзор работ по палиностратиграфии мела приведен в работе А.Ф. Хлоновой (1974). В большинстве из них содержатся сведения о ПК нерасчлененного сеномана-турона или условно выделяемого сеномана, без четких отличий от ниже- и вышерасположенных комплексов, за исключением количественных показателей некоторых компонентов, в основном пыльцы покрытосеменных неясной систематической принадлежности. Однако детальные морфологические и биостратиграфические исследования палинологов последних трех десятилетий позволили выявить характерные особенности палинокомплексов сеномана и отделить их от альбских и туронских комплексов (Стрепетилова, 1979a, 1979б, 1980, 1989; Хлонова, 1988; Микрофитофоссилии..., 1994 и др.). В то же время для южных территорий Западной Сибири (Хлонова, 1974; Лебедева и др., 2013; Лебедева, Кузьмина, 2018 и др.) и Южного Зауралья (Верхнемеловые..., 1990) попрежнему существуют трудности в опознавании палинокомплексов сеномана и турона в континентальных отложениях и даются сведения только о нерасчлененных ПК сеномана-турона.

Характерными особенностями сеноман-туронских ПК являются большое разнообразие споровых растений, особенно представителей семейств Schizaeaceae, Gleicheniaceae, Polypodiaceae, значительное участие спор печеночных мхов (Aequitriradites, Rouseisporites, Foraminisporis, Coptospora и др.), а также присутствие формальных таксонов Taurocusporites reduncus, Stenozonotriletes radiatus Chlon. Содержание пыльцы покрытосеменных в среднем составляет 8-10\%. Это в основном трехбороздная, реже трехпоровая пыльца. Для южных территорий доля 


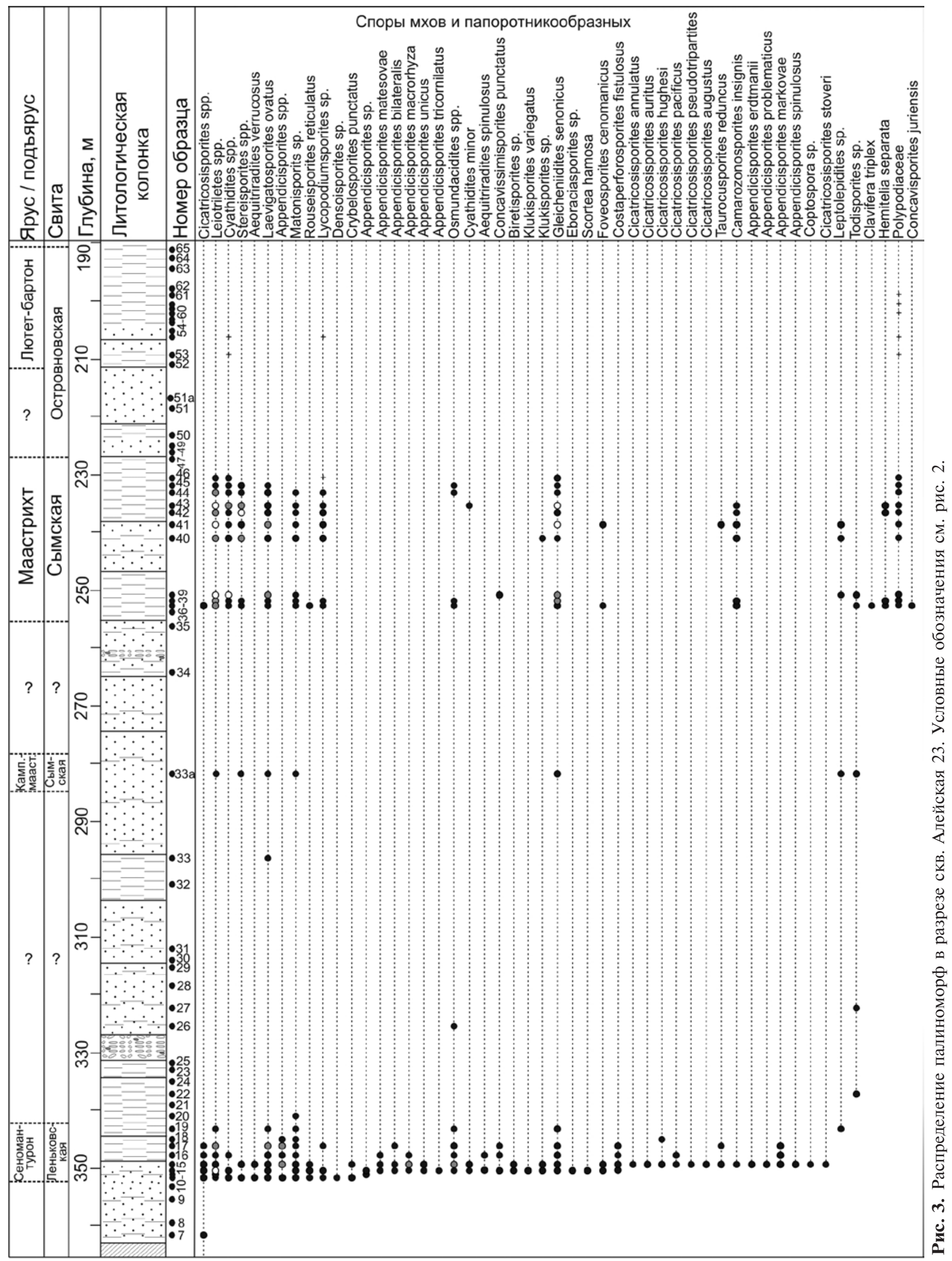




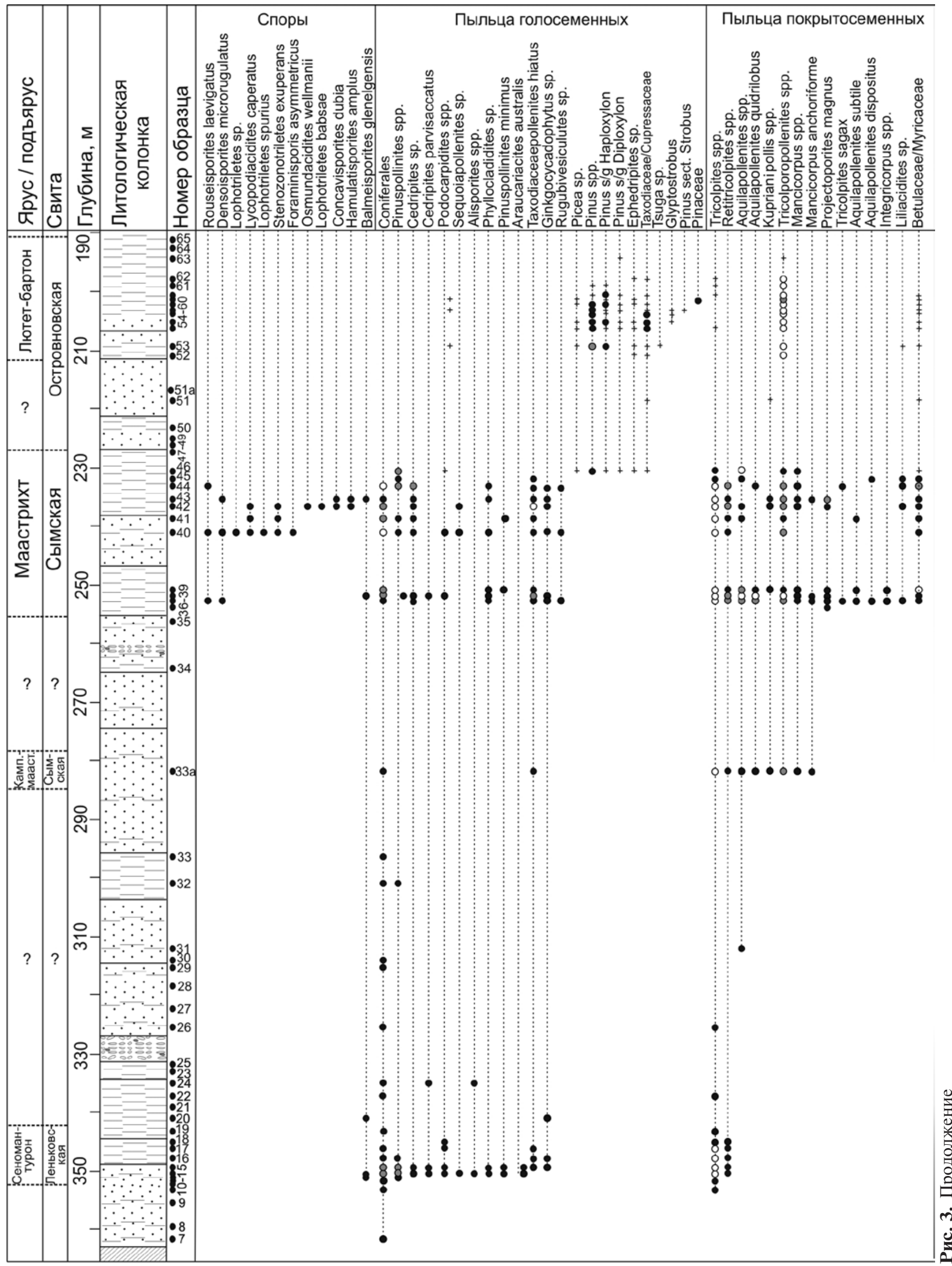




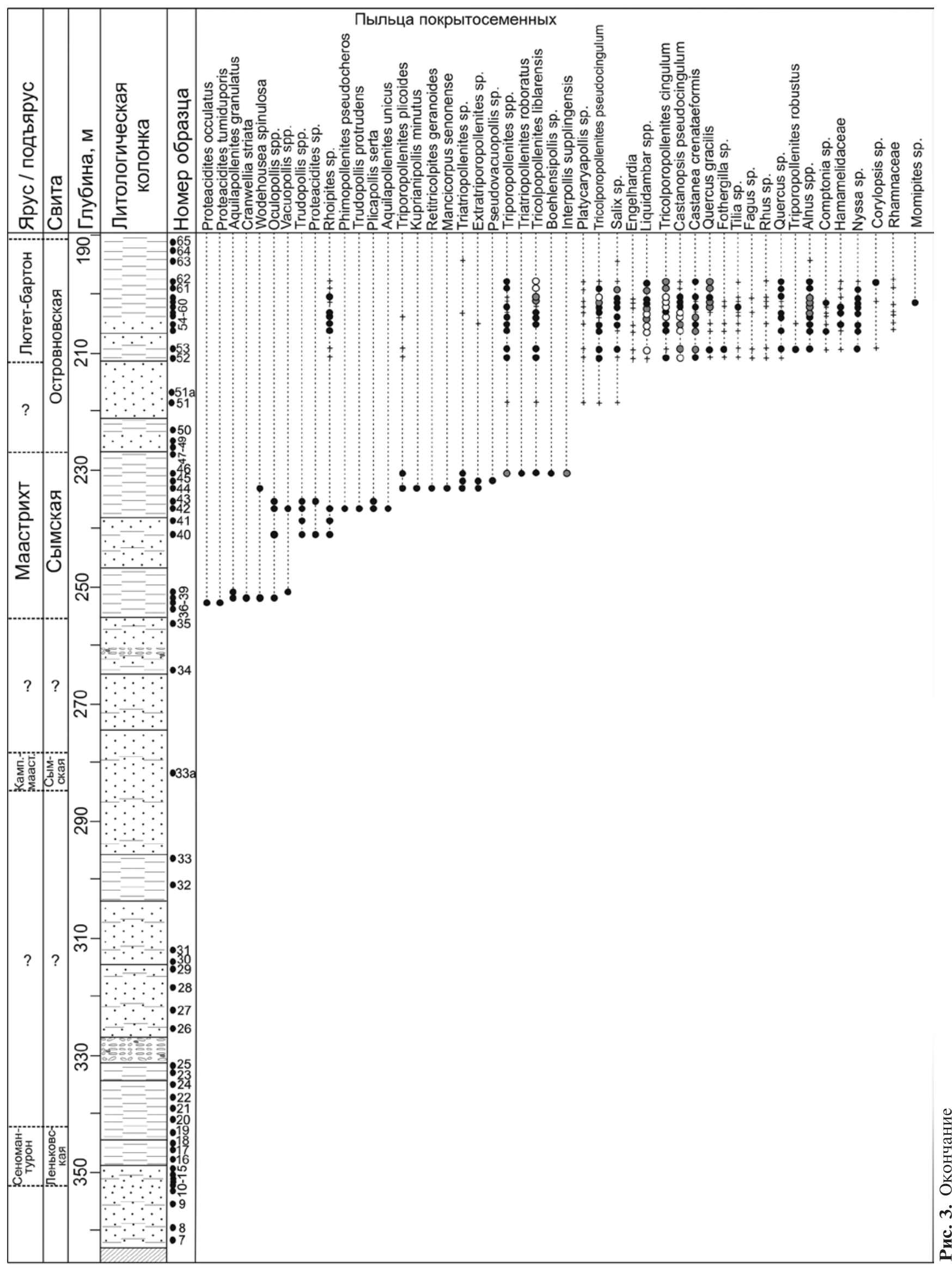




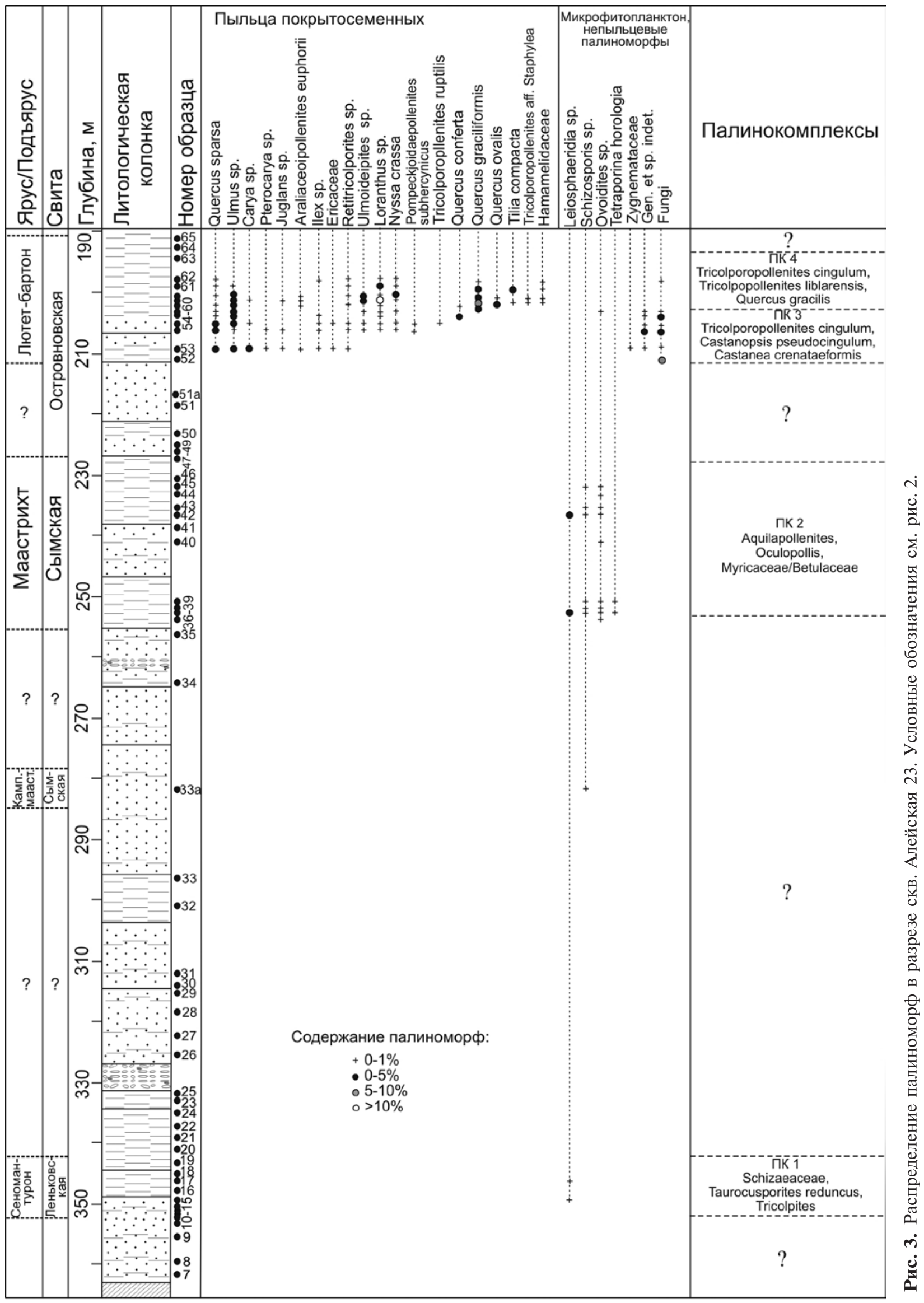


пыльцы может увеличиваться до 80\%.

Спорово-пыльцевые комплексы из леньковской свиты на территории Алтайского края, по данным М.А. Седовой, С.А. Климко, 3.А. Кругловой, 3.А. Войцель, И.М. Покровской, Л.Г. Марковой, позволили датировать ее альбом-сеноманом или сеноманом-туроном (Адаменко, 1974). Наиболее полные комплексы получены Э.А. Бессоненко по скважинам 1-М (оз. Малиновое, инт. 319.3321.3 м), 526 (с. Завьялово, гл. 508 м), 7 (РечкаКормиха, инт. 383-387 м), 22 (с. Симоново, гл. 292 м), 4 (оз. Рублево, гл. 304 м) и другим (Адаменко, 1974). Состав палиноморф в представленном ими комплексе аналогичен таковому в скв. Алейская 23, за исключением несколько меньшего количества пыльцы голосеменных и большего процентного содержания пыльцы покрытосеменных в последнем.

Таким образом, возраст отложений, вмещающих ПК Schizaeaceae, Taurocusporites reduncus, Tricolpites в скв. Алейская 23, можно определить как сеноман-туронский.

В изученном интервале С.Н. Бабенко из одного образца выделила спорово-пыльцевой спектр кампанского возраста (Подобина и др., 2011), отличающийся присутствием спор схизейных, а в составе пыльцы покрытосеменных она приводит роды, определенные по естественной системе. Остается неясным, являются ли эти таксоны засорением или нет, поскольку для столь древних форм естественная система давно не применяется. В то же время характерные кампанские таксоны в списке отсутствуют.

Условия осадконакопления. В составе палиноморф комплекса из слоев с ПК 1 определены только споры и пыльца наземных растений. Мацерат представлен крупными неокатанными частицами углефицированного детрита, обрывками растительной ткани хорошей сохранности. Сходное строение палинологических комплексов наблюдается в верхнесеноманских отложениях долганской свиты (Лебедева, Зверев, 2003). Все это, вместе с литологической характеристикой пород, свидетельствует о континентальном режиме осадконакопления, что подтверждает выводы предшествующих исследований об озерноаллювиальном и делювиально-пролювиальном генезисе леньковской свиты.

Вышележашие отложения (гл. 340.9-297.9 м, обр. 20-33) палинологически практически не охарактеризованы. В указанном интервале встречены лишь единичные Coniferales gen. indet., Pinuspollenites spp., Laevigatosporites ovatus, Tricolpites spp. На глубине 304.1 м обнаружена пыльца покрытосеменных рода Aquilapollenites, появляющаяся обычно не ниже верхов турона.

В образце 33а на глубине 281.5 м определены споры Leiotriletes spp., Laevigatosporites ovatus,

Таблица І. Палиноморфы из верхнемеловых отложений скв. Алейская 23. Длина масштабной линейки приведена в мКм.

1 - Stereisporites psilatus (Ross) Pflug, гл. 241.3 м, обр. 40; 2 - Stereisporites antiquasporites (Wilson et Webster) Dettmann, гл. 237.1 м, обр. 42; 3 - Cingutriletes clavus (Balme) Dettmann, гл. 237.1 м, обр. 42; 4 - Gleicheniidites cirniidites (Cookson) Dettmann, гл. 237.1 м, обр. 42; 5 - Gleicheniidites senonicus Ross, гл. 236.7 м, обр. 43; 6 - Gleicheniidites radiatus (Bolchovitina) Bolchovitina, гл. 237.1 м, обр. 42; 7 - Plicifera delicata (Bolchovitina) Bolchovitina, гл. 241.3 м, обр. 40; 8 - Hemitelia separata Chlonova, гл. 236.7 м, обр. 43 ; 9 - Biretisporites sp., гл. 349.8 м, обр. $15 ; 10$ - Cyathidites sp., гл. 349.8, обр. 15; 11 - Concavissimisporites punctatus (Delcourt et Sprumont) Brenner, гл. 241.3 м, обр. 40; 12, 13 - Aequitriradites spinulosus (Cookson et Dettmann) Cookson et Dettmann, гл. 350.6 м, обр. 14; 14 - Rouseisporites reticulatus Pocock, гл. 350.6 м, обр. 14; 15 - Rouseisporites laevigatus Pocock, гл. 253.4 м, обр. 38; 16 - Staplinisporites sp., гл. 237.1 м, обр. 42; 17 - Appendicisporites macrorhyzus (Maljavkina) Bondarenko, гл. 350.6 м, обр. 14; 18 - Appendicisporites matesovae (Bolchovitina) Norris, гл. 349.8, обр. 15; 19 Appendicisporites unicus (Markova) Singh, гл. 350.6, обр. 14; 20 - Cicatricosisporites perforatus (Markova) Döring, гл. 349.8 м, обр. 15; 21, 22 - Lycopodiumsporites marginatus Singh, гл. 237.1 м, обр. 42; 23 - Lycopodiumsporites clavatoides Couper, гл. 253.4 м, обр. 37; 24 - Camarozonosporites insignis Norris, гл. 241.3 м, обр. 40; 25 - Laevigatosporites ovatus Wilson et Webster, гл. 241.3 м, обр. 40; 26 - Polypodiaceae, гл. 253.4 м, обр. 37 ; 27 - Cedripites parvisaccatus (Sauer) Chlonova, гл. 349.8 м, обр. 15; 28 - Phyllocladidites inchoatus (Pierce) Norris, гл. 349.8 м, обр. 15; 29 - Cedripites sp., гл. 241.3 м, обр. 40; 30 - Taxodiaceaepollenites hiatus (Pot.) Kremp., гл. 237.1 м, обр. 42; 31 Ephedripites costatus Bolchovitina, гл. 241.3 м, обр. 40; 32 - Aquilapollenites granulatus N. Mtchedlishvili, гл. 253.4 м, обр. 37; 33 - Menispermum turonicum N. Mtchedlishvili, гл. 349.8 м, обр. 15; 34 - Tricolpites sp., гл. 253.4 м, обр. 37; 35 - Aquilapollenites unicus (Chlonova) Chlonova, гл. 253.4 м, обр. 37; 36 - Aquilapollenites cruciformis N. Mtchedlishvili, гл. 253.4 м, обр. 38; 37 - Aquilapollenites subtilis N. Mtchedlishvili, гл. 241.3 м, обр. 40; 38 Mancicorpus senonicum N. Mtchedlishvili, гл. 253.4 м, обр. 38; 39 - Mancicorpus anchoriforme N. Mtchedlishvili, гл. 253.4 м, обр. 37; 40, 41 - Tricolpites sagax Norris, 40 - гл. 253.4 м, обр. 38, 41 - гл. 253.4 м, обр. 37; 42, 43 - Projectoporites unicus N. Mtchedlishvili, гл. 253.4 м, обр. 37; 44 - Projectoporites ovalis N. Mtchedlishvili, гл. 253.4 м, обр. 37; 45 - Projectoporites magnus N. Mtchedlishvili, гл. 253.4 м, обр. 37; 46 - Proteacidites tumidiporis Samoilovitch, гл. 236.7 м, обр. 43; 47 - Cranwellia striata (Couper) Srivastava, гл. 253.4 м, обр. 38 ; 48 - Trudopollis protrudens Pflug, гл. 241.3 м, обр. 40; 49 - Trudopollis bulbosus Zaklinskaja, гл. 237.1 м, обр. 42; 50 - Trudopollis ordinatus Zaklinskaja, гл. 237.1 м, обр. 42; 51 - Ocullopollis sp., гл. 236.7 м, обр. 43; 52 - Kuprianipollis sp., гл. 253.4 м, обр. 37; 53 - Tricerapollis minimus Chlonova, гл. 253.4 м, обр. 38. 


\section{Таблица I}
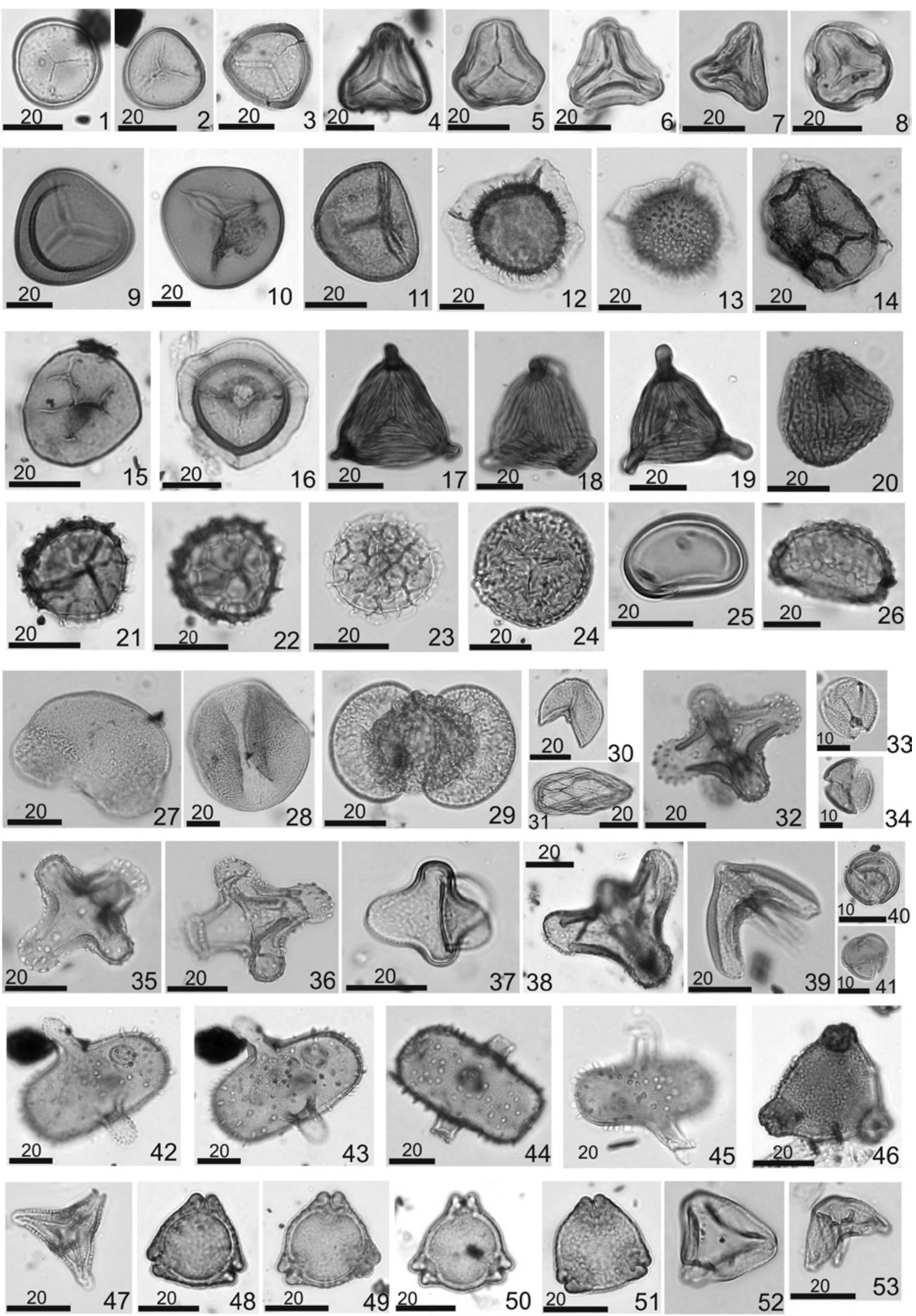

СТРАТИГРАФИЯ. ГЕОЛОГИЧЕСКАЯ КОРРЕЛЯЦИЯ Том 27 № 62019 
Таблица II
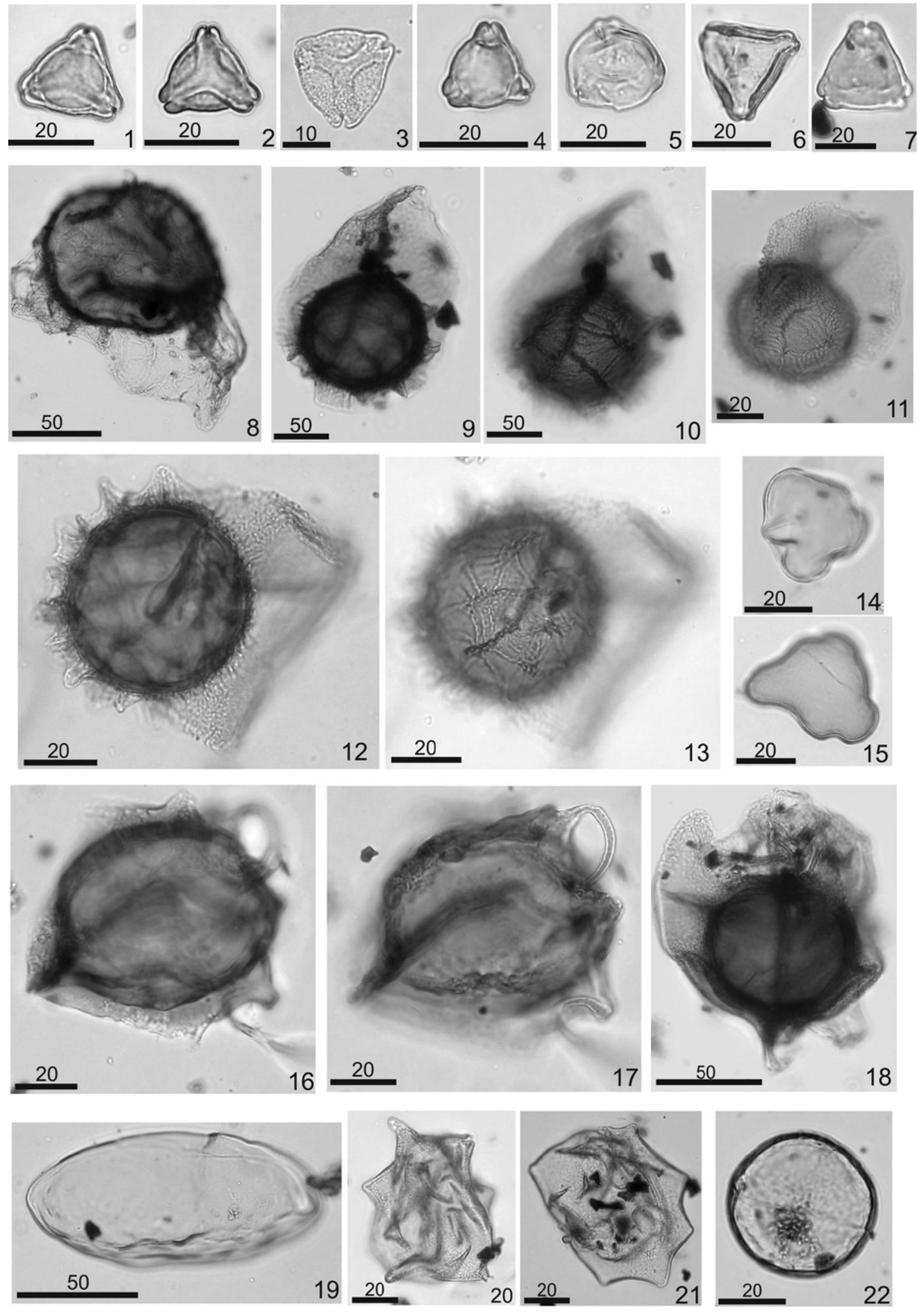
Таблица II. Палиноморфы из верхнемеловых отложений скв. Алейская 23. Длина масштабной линейки приведена в мкм.

1, 2 - Plicapollis serta Pflug, гл. 237.1 м, обр. 42; 3 - Plicapollis retusus Tschudy, гл. 253.4 м, обр. 37 ; 4 - Extrariporopollenites sp., гл. 237.1 м, обр. 42; 5 - Betulaceae/Myricaceae, гл. 253.4 м, обр. 38; 6 - Triporopollenites plicoides Zaklinskaja, гл. 253.4 м, обр. 38; 7 - Momipites coryloides Wodehouse, гл. 253.4 м, обр. 37; 8 - Balmeisporites glenelgensis Cookson et Dettmann, гл. 350.6 м, обр. 14; 9, 10, 11 - Ghoshispora kondinskayae (Srivastava et Binda) Srivastava, гл. 253.4 м, обр. 37; 12, 13 - Ghoshispora aff. bella (Kondinskaya) Srivastava, гл. 253.4 м, обр. 37; 14, 15 - Microphytofossils gen. indet., гл. 253.4 м, обр. 37; 16, 17 - Ariadnaesporites sp., гл. 253.4 м, обр. 37 ; 18 Megaspore gen. indet., гл. 253.4 м, обр. 37; 19 - Ovoidites sp., гл. 253.4 м, обр. 38; 19, 20, 21 - Microphytofossils indet., гл. 253.4 м, обр. 37; 22 - Schizosporis sp., гл. 241.3 м, обр. 40.

Matonisporites sp., Gleicheniidites sp., Leptolepidites sp., Stereisporites sp., пыльца голосеменных Coniferales gen. indet., Taxodiaceaepollenites sp. Наиболее многочисленна пыльца покрытосеменных, представленная Tricolpites spp., Retitricolpites spp., Tricolporopollenites sp., Kuprianipollis sp., Mancicorpus sp., M. anchoriforme N. Mtchedlishvili, Aquilapollenites quadrilobus Rouse, указывающая на возраст не древнее кампана.

Выше по разрезу до глубины 254.8 образцы не содержат палиноморф.

Слои с ПК 2 Aquilapollenites, Oculopollis, Myricaceae/Betulaceae (нижний инт. 256253 м, верхний инт. 232.2-227.5 м; обр. 37-46), сымская свита.

Содержание спор мхов и папоротникообразных составляет 12-51\%, пыльцы голосеменных 5-24\%, пыльцы покрытосеменных - 40-73\%, микрофитопланктона $-0-4 \%$.

В составе спор определены Leiotriletes spp., Foveosporites sp., Laevigatosporites ovatus, Cyathidites sp., Matonisporites sp., Gleicheniidites sp., Camarozonosporites insignis, Osmundacidites sp., Lycopodiumsporites sp., Stereisporites spp., Rouseisporites reticulatus, R. laevigatus, Clavifera triplex, Cicatricosisporites sp., Hemitelia separata, Polypodiaceae, Leptolepidites sp., Foraminisporis sp. и др. Много разнообразных спор водных папоротников (табл. II).

Пыльца голосеменных представлена Coniferales gen. indet., Taxodiaceaepollenites sp., Cedripites spp., Pinuspollenites spp., Ginkgocycadophytus sp., Phyllocladidites sp., Podocarpidites spp., Sequoiapollenites sp., Rugubivesiculites sp.

Пыльца покрытосеменных доминирует в комплексе и очень разнообразна. Определены Tricolpites spp., Retitricolpites spp., Tricolporopollenites sp., Aquilapollenites spp., A. quadrilobus, A. granulatus N. Mtchedlishvili, A. subtilis N. Mtchedlishvili, A. unicus (Chlonova) Chlonova, A. magnus Samoilovitch, Mancicorpus sp., M. anchoriforme N. Mtchedlishvili, Cranwellia striata (Couper) Srivastava, Myricaceae/Betulaceae, Oculopollis sp., Kuprianipollis sp., Integricorpus sp., Vacuopollis sp., Trudopollis sp., Proteacidites spp., Rhoipites sp., Plicapollis serta, Triorites harrisii
Couper, Extratriporopollenites sp. и др.

Микрофитопланктон представлен пресноводными Schizosporis sp., Ovoidites sp., Leiosphaeridia sp., Tetraporina horologia (Staplin) Playford.

Установленный палинокомплекс соответствует составу палиноморф верхнесымской подсвиты сымской свиты (Решение..., 1991). Палинологическое изучение сымской свиты проводилось как в естественных выходах (Ковалева, 1953; Хлонова, 1957, 1960, 1961; Пыльца..., 1961; Григорьева, 1965), так и в керне скважин (Маркова, Широкова, 1960; Пыльца..., 1961 и др.). В цитируемых работах приведены таксономический состав палиноморф, обоснование возраста, сопоставление с палинологическими комплексами из морских отложений, датированных по различным группам фауны. История изучения сымской свиты отражена в работе А.Ф. Хлоновой (1974), где, используя особенности сымского комплекса, она сопоставляет континентальные отложения восточной части Западной Сибири с прибрежно-морскими и морскими отложениями ганькинской свиты, развитой в ее центральной части. А.Ф. Хлонова также указывает, что основные особенности маастрихт-датских спорово-пыльцевых комплексов проявляются в составе пыльцы покрытосеменных: по сравнению с сантон-кампанскими комплексами, в них увеличивается количество и разнообразие Aquilapollenites, Mancicorpus, Integricorpus, Wodehouseia, Orbiculapollis, уменьшается роль Kuprianipollis, не встречены Chlonovaia sibirica, Tricerapollis minimus. В изученной нами скв. Алейская 23 присутствует также пыльца стеммы Normapolles, что характерно для территорий, находившихся в зоне влияния как Сибирско-Канадской провинции Aquilapollenites, так Европейско-Синийской Normapolles.

По сопоставлению с фаунистически охарактеризованной ганькинской свитой верхнесымская подсвита в настоящее время датируется маастрихтом, маастрихтом-данием (Решение..., 1991).

Условия осадконакопления. Выявленные комплексы палиноморф содержат споры и пыльцу наземных растений, споры водных папоротни- 
Таблица III
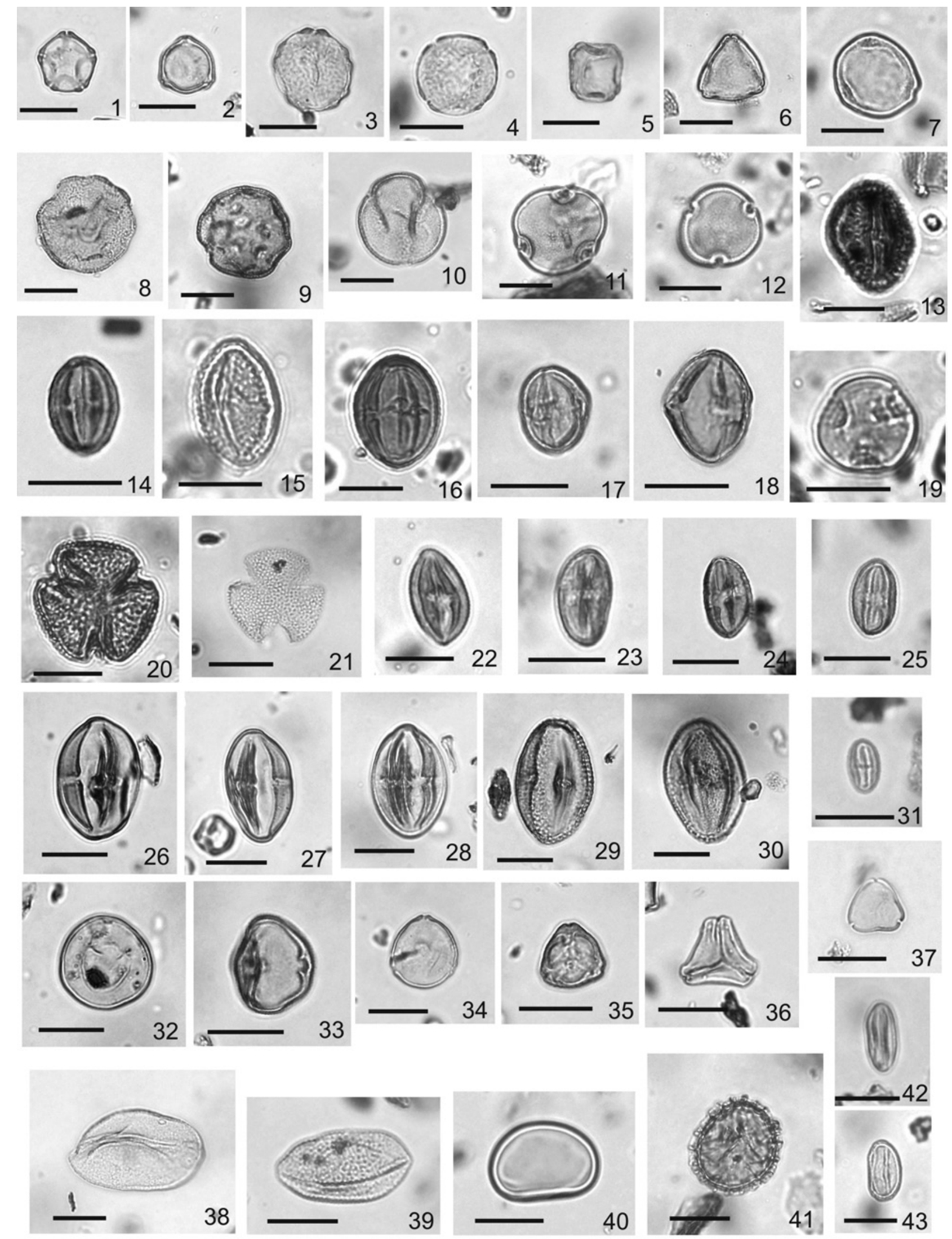
Таблица III. Пыльца и споры из островновской свиты (эоцен), скв. Алейская 23. Длина масштабной линейки 20 мКм.

Фиг. 2, 5, 6, 10, 31, 38, 39, 41, 42 - гл. 209.4 м, обр. 53; фиг. 1, 3, 4, 8, 9, 11-30, 32, 33-37, 40 - гл. 206.4 м, обр. 55; фиг. 7, 43 - гл. 202.4 м, обр. 58.

1 - Alnus sp.; 2 - Corylus sp.; 3, 4 - Ulmus sp.; 5 - Ulmoideipites sp.; 6 - Triatriopollenites sp.; 7 - Platycaryapollis sp.; 8, 9 - Liquidambar sp.; 10 - Quercus sparsa; 11, 12 - Tilia sp.; 13 - Rhoipites sp.; 14 - Tricolporopollenites sp.; 15 - Tricolporopollenites aff. heterobrochatus I. Kulkova; 16 - Rhoipites sp.; 17 - Tricolporopollenites sp.; 18 - Araliaceoipollenites euphorii; 19 - Tricolpopollenites ruptilis I. Kulkova; 20, 29, 30 - Retitricolporites sp.; 21 Hamamelidaceae; 22-24 - Castanopsis spp., 25 - Tricolporopollenites cingulum; 26-28 - Rhoipites sp.; 31 - Castanea crenataeformis; 32 - Carya sp.; 33 - Nyssa sp.; 34 - Comptonia sp.; 35 - Pompeckjoidaepollenites subhercyinicus; 36 - Loranthus sp.; 37 - Engelhardia sp.; 38, 39 - Liliacidites sp.; 40 - Polypodiaceae; 41 - Lycopodiaceae; 42 Tricolpopollenites liblarensis; 43 - Quercus gracilis.

ков и пресноводный микрофитопланктон. Облик мацерата с крупными неокатанными остатками растительных тканей также указывает на континентальный (скорее всего, со спокойной гидродинамикой), возможно озерный, генезис верхнесымской подсвиты.

На глубине 227.7 м глины верхнесымской подсвиты сменяются песками буровато-серыми, с включением лигнита (рис. 2), которые практически не содержат спор и пыльцы (инт. 227.5-210.4 м, обр. 47, 48, 51, 51a). Только в образцах 48 (гл. 227 м), 51 (гл. 219.3 м), 51а (гл. 216.1 м) обнаружены единичные пыльцевые зерна, принадлежащие Triatriopollenites roboratus, Triporopollenites plicoides, Triporopollenites sp., Tricolpites sp., Tricolporopollenites pseudocingulum (Potonie) Thomson et Pflug, Tricolpopollenites liblarensis, Picea sp., Taxodiaceae/Cupressaceae. Эти пески, предположительно, относятся к островновской свите палеогенового возраста.

Слои с ПК 3 Tricolporopollenites cingulum, Castanopsis pseudocingulum, Castanea crenataeformis (инт. 210.4-202.4 м, обр. 52-57), островновская свита.

В ПК 3 доминирует пыльца покрытосеменных (80-99\%). На первом месте по встречаемости находится пыльца формального рода Tricolporopollenites (суммарно от 19.5 до 46.2\%) с видами Т. cingulum, Т. pseudocingulum. Субдоминантной является пыльца Castanopsis pseudocingulum (R. Potonie) Boitzova (8.5-34.5\%), Castanea crenataeformis Samigulina (4-6.7\%), а также Liquidambar sp. (7-24.5\%). В незначительных количествах (не более 5\%) присутствует пыльца Tricolpopollenites liblarensis, Triporopollenites plicoides, Triporopollenites sp., Retitricolporites sp., Tricolporopollenites aff. Rhamnaceae, Rhoipites granulatus (Frederiksen) Boitzova, Rhoipites spp., Platycaryapollis sp., Araliaceoipollenites euphorii R. Potonie, Araliaceoipollenites sp., Alnus sp., Salix sp., Ulmus sp., Ulmoideipites sp., Quercus gracilis, Q. sparsa, Q. conferta Boitzova, Quercus sp., Engelhardia sp., Nyssa crassa Panova, Nyssa sp., Myrica sp. Единично отмечена пыльца
Pompeckjoidaepollenites subhercinicus (W. Krutzsch) W. Krutzsch, Hamamelidaceae, Fothergilla sp., Ilex sp., Carya sp., Comptonia sp., Loranthus sp., Tilia sp., Fagus sp. (табл. III).

Пыльца голосеменных в ПК 3 немногочисленна (не более 9\%) и представлена Pinus spp. (2.6-6.3\%), Pinus s/g Haploxylon et Diploxylon, Pinus sect. Strobus, Picea sp., единичными зернами Podocarpus sp., Ephedra sp., Taxodiaceae/ Cupressaceae, Tsuga sp., Glyptostrobus sp.

Споры также единичны, спорадически встречаются Polypodiaceae, Cyathea sp., Lycopodiaceae, Gleichenia sp.

Непыльцевые палиноморфы представлены в основном спорами грибов, которые зачастую составляют до $10 \%$ ПК (табл. IV). Микрофитопланктона очень мало, обнаружены единичные представители сем. Zygnemataceae (Ovoidites sp. и др.), а также неопределенные до рода и вида круглые формы (табл. IV, фиг. 12-14).

Большое количество мелкой трехбороздно-поровой пыльцы (Tricolporopollenites, Castanopsis, Castanea), присутствие пыльцы кверкоидного типа Quercus gracilis, Q. graciliformis, полное отсутствие пыльцы Normapolles, а также увеличение разнообразия пыльцы естественных таксонов указывают на среднеэоценовый возраст палинокомплекса (Практическая..., 1990). Близкий к ПК 3 палинокомплекс с Castanea crenataeformis-Castanopsis pseudocingulum был выделен О.Н. Васильевой (1990) из нижней части чеганской свиты в Зауралье. Из этих же отложений О.Н. Васильевой (1990) выделен Lentinia serrata Bujak - вид, появляющийся в низах динозоны Rhombodinium porosum (бартон) (Яковлева, Александрова, 2013). Сходный по составу палинокомплекс с Castanea crenataeformis, Castanopsis pseudocingulum, Rhoipites pseudocingulum описан И.А. Кульковой (Микрофитофоссилии..., 1988) из зеленовато-серых глин в скв. 37 (Обь-Иртышское междуречье); она оценила его возраст как среднеэоценовый. Близкий к ПК 3 палинокомплекс, совместно с комплексом диноцист, характерным для бартона, выделен О.Б. Кузьминой из юрков- 


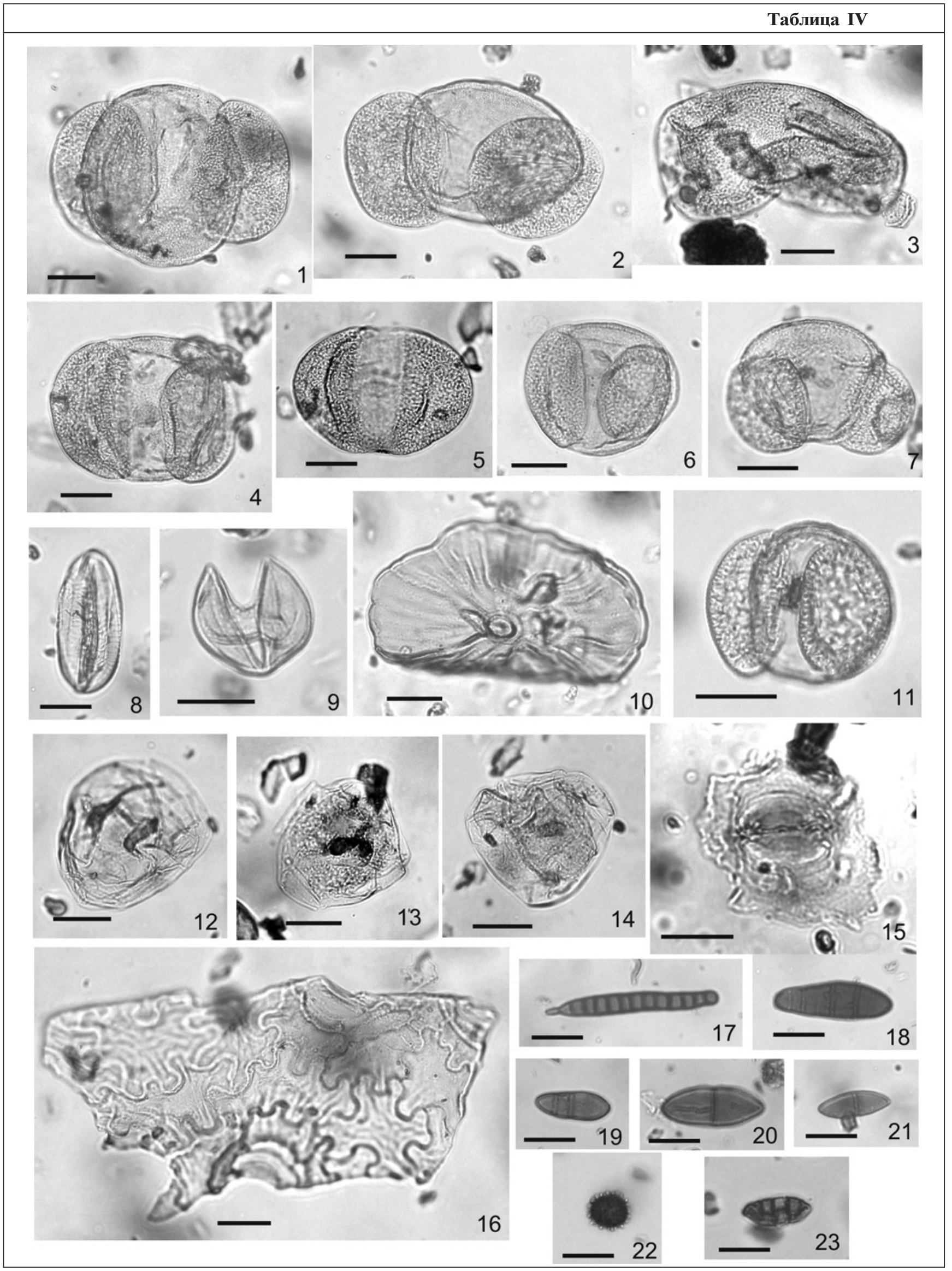


Tаблица IV. Пыльца голосеменных растений и непыльцевые палиноморфы из островновской свиты, скв. Алейская 23. Длина масштабной линейки 20 мкм.

Фиг. 1-5, 9, 10 - гл. 209.4 м, обр. 53; фиг. 6-8, 11, 14-23 - гл. 206.4 м, обр. 55.

1, 2 - Abies sp.; 3 - Picea sp.; 4, 5 - Pinis s/g Haploxylon; 6, 7, 11 - Pinis s/g Diploxylon; 8 - Ephedra sp.; 9 Taxodiaceae/Cupressaceae; 10 - Fruiting bodies; 12-14 - Microptytoplankton gen. et sp. indet.; 15 - Coniferales stomata; 16 - эпидермис Pinaceae; 17-23 - Fungal spore: 17-19 - Multicellata-type, 20, 21 - Dicellata-type, 22 - Ustilago (?)-type, 23 - Alternaria-type.

ской (?) свиты в Притомском литофациальном районе Западно-Сибирской равнины (Лебедева и др., 2017). Комплекс с доминированием трехбороздно-поровой пыльцы (Tricolporopollenites cingulum и др.) выявлен в тавдинской свите на севере Западной Сибири, где отложения охарактеризованы бартонским комплексом диноцист с Lentinia serrata (Iakovleva, Kulkova, 2001). Упоминается, что на этом уровне как раз появляются виды Quercus gracilis, Q. graciliformis. Таким образом, отложения островновской свиты (инт. 210.4-202.4 м) в скв. Алейская 23, содержащие ПК 3, следует относить к среднему эоцену (лютет-бартон).

Условия осадконакопления. Отсутствие в составе ПК 3 морского микрофитопланктона свидетельствует о формировании вмещающих отложений в континентальных условиях. Мацераты содержат крупные неокатанные остатки растительных тканей (эпидермис и устьица хвойных растений; табл. IV). Спорово-пыльцевые спектры на 80-90\% состоят из пыльцы покрытосеменных растений, что говорит о накоплении осадка в прибрежной части бассейна. Высокий процент участия пыльцы рода Liquidambar указывает на то, что территории, прилегавшие к бассейну седиментации, представляли собой низинные, временами затопляемые, возможно, болотистые равнины (Magri et al., 2017); климат был умеренно-теплый и влажный.

Следует отметить, что, согласно микропалеонтологическим данным, полученным В.М. Подобиной с соавторами (2011), отложения инт. 229.5-200 м в скв. Алейская 23 полностью относятся к талицкому региональному горизонту (даний-зеландий) Западно-Сибирской равнины. Подобиной с соавторами (2011) в скв. Алейская 23 были выявлены два палинокомплекса с гл. 229.0 и 206.0 м. Для первого характерны такие таксоны, как Quercus gracilis Boitzova, Q. graciliformis Boitzova, Q. sparsa Martynova, а также множество мелкой трехбороздной пыльцы, на основании чего вмещающие отложения датированы маастрихтом-данием (Подобина и др., 2011). Второй комплекс (гл. 206.0 м) с обилием трехбороздной, трехбороздно-поровой пыльцы (Tricolporopollenites, Castanea, Castanopsis и др.) Подобина и др. счи- тают палеоцен-эоценовым, но, согласно рис. 2 (Подобина и др., 2011), относят вмещающие отложения к палеоцену (зеландий). Следует отметить, что состав и структура описанных Подобиной и др. палинокомплексов, особенно присутствие таких таксонов, как Quercus gracilis, Q. graciliformis, не позволяют считать их типично палеоценовыми. З.Н. Гнибиденко с соавторами (2017), основываясь на выводах В.М. Подобиной и др. (2011), также выделяют талицкую свиту в скв. 23, что, на наш взгляд, вызывает большие сомнения. Известно, что талицкая свита, широко распространенная на севере и в центральной части Западной Сибири (Iakovleva, Kulkova, 2001; Бакиева, 2003), в Среднем и Южном Зауралье (Васильева, 1990, 2003; Амон и др., 2003) и редко встречающаяся на юге Западной Сибири (Зальцман, 1968; Яковлева, Александрова, 2013), имеет морское происхождение, обоснованное присутствием фораминифер, диноцист, радиолярий, диатомовых, силикофлагеллат (Унифицированные..., 2001). Отложения включают спорово-пыльцевые комплексы палинозон СП3-1 и СП3-2, содержащие значительную долю пыльцы стеммы Normapolles (Trudopollis Nudopollis, Extratriporopollenites, Oculopollis). М.А. Ахметьев с соавторами (2004) проанализировал публикации 1960-х годов, посвященных этому вопросу, и пришел к выводу, что в большинстве скважин центральной и южной частей Барабинской зоны, а также в Кулундинской зоне талицкая свита отсутствует в результате крупной раннепалеогеновой регрессии. Полученные нами данные также не дают оснований для выделения в разрезе скв. Алейская 23 талицкой свиты. Исключительно наземный характер палиноморф ПК 3 и отсутствие фораминифер свидетельствуют о накоплении вмещающих отложений в условиях континентального пресноводного водоема. В разрезе также не выявлены палинокомплексы, характерные для палеоцена-нижнего эоцена. Мы полагаем, что в скв. Алейская 23 верхнемеловая сымская свита с перерывом перекрывается среднеэоценовыми слоями, принадлежащими островновской свите палеогенового возраста (Унифицированные..., 2001). 


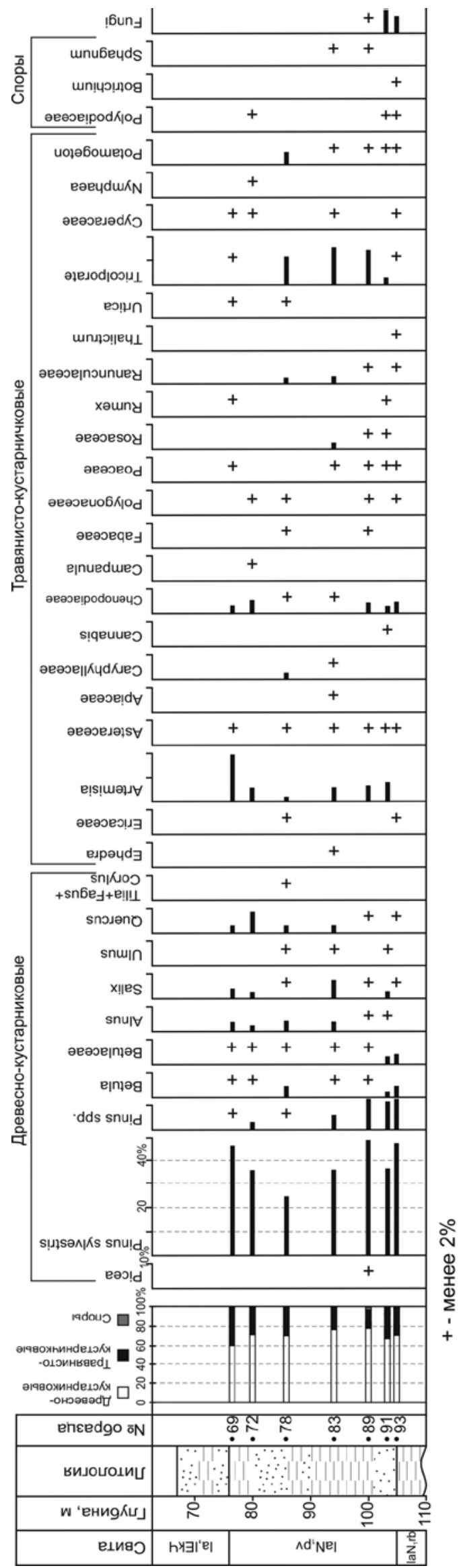

Слои с ПК 4 Tricolporopollenites cingulum, Tricolpopollenites liblarensis, Quercus gracilis (инт. 202.4-198.5 м, обр. 58-62). Комплекс включает те же таксоны, что и ПК 3 , однако соотношение основных компонентов в этом комплексе другое. Доминирует по-прежнему разнообразная пыльца, принадлежащая формальному роду Tricolporopollenites (33-49.3\%), а субдоминантной является пыльца Tricolpopollenites liblarensis $(4.8-26 \%)$ и Quercus gracilis, Q. graciliformis (суммарно 4.5-15\%). По сравнению с ПК 3, значительно уменьшается доля пыльцы Castanopsis (0.5-3.5\%), Castanea (0.3-1.7\%), а также Liquidambar (2.5-8.3\%). Кроме того, ПК 4 отличается постоянным присутствием пыльцы Loranthus sp. (в среднем 0.5-2.5\%), максимальное количество которой отмечено в обр. 59 (гл. 200.9 м) и составляет около $10 \%$ ПК.

Пыльца голосеменных малочисленна (1.53\%) и представлена единичными зернами Pinus spp., Pinus s/g Haploxylon et Diploxylon, Pinus sect. Strobus, Picea sp., Podocarpus sp., Ephedra sp., Taxodiaceae/Cupressaceae.

Споры встречаются редко $(<1 \%)$ и принадлежат сем. Polypodiaceae.

Палинокомплекс 4 имеет сходство с комплекcom Quercus gracilis-Rhoipites pseudocingulum, выделенным О.Н. Васильевой (1990) из чеганской свиты в Южном Зауралье. Основу последнего составляет пыльца трехбороздно-порового строения, наряду с этим значительный удельный вес приобретает пыльца кверкоидного типа, принадлежащая Quercus gracilis, Q. graciliformis, Tricolpopollenites liblarensis и др. (Васильева, 1990). Из тех же отложений О.Н. Васильевой (1990) выявлен Rhombodinium ornatum (=Kisselovia ornata) (Vozzhennikova) Williams et al. - вид-индекс одноименной зоны (бартон). Комплекс Castanopsis pseudocingulumRhoipites pseudocingulum-Quercus gracilisTricolpopollenites liblarensis совместно с комплексом диноцист бартона (Rhombodinium ornatum (=Kisselovia ornata), Rhombodinium irtyschense (=Wetzeliella irtyschensis) (Alberti) Williams et al. и др.) описан И.А. Кульковой (Микрофитофоссилии..., 1988) из зеленых плотных глин в скв. 37 (Обь-Иртышское междуречье). Близкий к ПК 4 палинокомплекс c Tricolporopollenites cingulum, Castanopsis pseudocingulum, Quercus graciliformis выявлен в морских отложениях среднего эоцена (низы бартонского яруса) Казахстана (Практическая..., 1990). Таким образом, породы, включающие ПК 4 (инт. 202.4-198.5 м), могли формироваться во второй половине среднего эоцена (бартон).

Условия осадконакопления. В ПК 4 присутствуют только пыльца и споры наземных рас- 
тений, из чего следует, что накопление отложений происходило в условиях континентального пресноводного водоема. Отличительной чертой ПК 4 является наличие значительного количества пыльцы, принадлежащей роду Loranthus кустарнику, паразитирующему на древесной растительности. В настоящее время он произрастает преимущественно в тропическом поясе, а один его вид встречается в Крыму и в Восточной Европе. В отличие от омелы, паразитирующей на разных кустарниках, Loranthus паразитирует на дубах. Вполне возможно, что значительное количество такой пыльцы в ПК 4 является следствием возросшей роли дубов в составе древесной растительности.

Слои с ПК 5 Pinaceae, Artemisia, Chenopodiaceae (инт. 105-77.5 м, 7 образцов), павлодарская свита. В разрезе скважины павлодарская свита залегает на нижненеогеновой рубцовской свите (150-105 м) и перекрывается эоплейстоценовой кочковской свитой (77.5-22.8 м).

Из особенностей спорово-пыльцевых спектров, включенных в ПК 5, стоит отметить невысокую концентрацию палиноморф. Преобладает пыльца древесно-кустарничковых растений (более $60 \%$ ), главным образом пыльца сосен Pinus aff. sylvestris, Pinus spp. (рис. 4). Менее распространена пыльца Salix, Alnus, Betula, Quercus, отмечены единичные зерна пыльцы Ulmus, Tilia, Corylus. Доля пыльцы травянисто-кустарниковых растений в ПК 5 составляет 22-40\%, в основном она представлена Artemisia, Chenopodiaceae и трехбороздно-поровыми пыльцевыми зернами (рис. 4). Присутствует также пыльца сем. Asteraceae, Poaceae, Polygonaceae, Ranunculaceae, Rosaceae, Fabaceae и др. Пыльца водно-болотных растений принадлежит Potamogeton, Cyperaceae, в одном образце отмечены единичные зерна пыльцы Nymphaea. Споры мхов и папоротников редки. В нескольких спектрах присутствуют споры грибов.

Павлодарская свита входит в состав одноименного регионального горизонта и, согласно стратиграфической схеме (Унифицированная..., 2001), включает степные и полупустынные растительные ассоциации с Chenopodiaceae, Poaceae, Apiaceae, Cichoritaceae, Artemisia, Ephedra, с участием Quercus, Ulmus. Споровопыльцевые спектры, выделенные из павлодарской свиты, характеризуются высоким содержанием пыльцы травянистых растений. Так, из павлодарской свиты в скв. 79 (Алейская ложбина) Э.А. Бессоненко (Русанов, 2009) выявила спектры, состоящие преимущественно из полыней, злаков и маревых с примесью разнотравья; пыльца древесных в этих спектрах составляет от 20.7 до 36.9\% и представлена пыльцой тургайской флоры, но обедненного видового состава.
Южнее, в стратотипическом разрезе павлодарской свиты Гусиный перелет у г. Павлодар, спорово-пыльцевой комплекс также состоит преимущественно из пыльцы травянисто-кустарничковой растительности: злаков, маревых, полыней и разнотравья (Терещенко, Зинова, 1981). ПК 5 сходен с комплексами, выявленными ранее из павлодарской свиты, по высокому содержанию пыльцы ксерофитных трав - полыней, маревых и других представителей разнотравья, но отличается большим количеством пыльцы сосновых. Это можно объяснить тем, что подобная пыльца - одна из самых летучих и может разноситься на расстояния до 1000 км; в безлесных районах доля заносной пыльцы сосны в спектрах может доходить до $30 \%$ (Бляхарчук, 2010). Э.А. Бессоненко (Адаменко, 1974) также указывает, что в некоторых спектрах из павлодарской свиты количество пыльцы хвойных может увеличиваться до 45\%, что она объясняет близостью района к горным сооружениям Алтая. Высокое содержание пыльцы сосны в ПК 5 может являться локальной особенностью данного разреза.

Таким образом, палинологические данные позволяют обосновать позднемиоценовый возраст отложений из инт. 105-77.5 м и подтверждают их принадлежность павлодарской свите.

Образцы, отобранные из кочковской свиты (эоплейстоцен), не содержат спор и пыльцы.

\section{Скважина Алейская 19}

В скв. Алейская 19 (рис. 5) прослежены слои с ПК 2 (инт. 267.4-262.1 м; обр. 16а, 17, 19). Морской микрофитопланктон не обнаружен. В разрезе данной скважины, так же как и в скв. Алейская 23, вскрыта не ганькинская свита морского генезиса (Гнибиденко и др., 2017), а континентальная верхнесымская подсвита (маастрихт).

Из палеогеновой части разреза скв. Алейская 19 было изучено два образца (инт. 224.7222.1 м; обр. 20, 21), в которых выявлены спорово-пыльцевые спектры с преобладанием пыльцы голосеменных (82-87\%): примерно в равных количествах присутствует пыльца, принадлежащая сем. Pinaceae, Taxodiaceae/ Cupressaceae, Glyptostrobus. Пыльцы покрытосеменных немного (12-16\%), отсутствуют явные доминанты, обнаружены Triatriopollenites roboratus, T. aroboratus, Tricolporopollenites sp., Triporopollenites sp., Tricolpopollenites liblarensis, Caryapollis sp., Platycaryapollis sp., Interpollis supplingensis, Interpollis sp., Momipites sp., Alnus sp., Quercus sparsa. Редкий пресноводный микрофитопланктон представлен Leiosphaeridia sp., Pediastrum boryanum. Описанные споровопыльцевые спектры отличаются по структуре от 


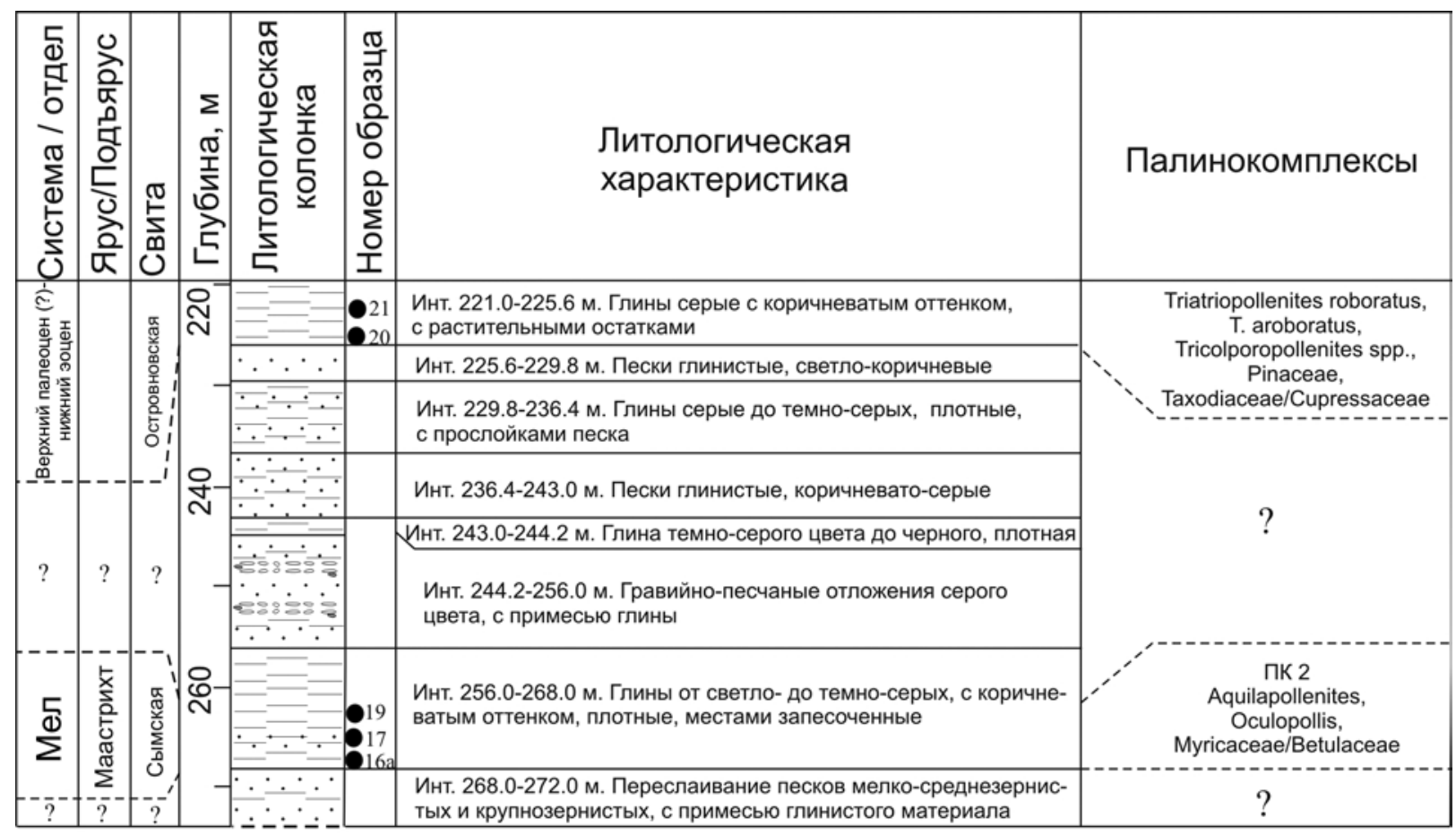

Рис. 5. Разрез скважины Алейская 19, его литологическое описание и биостратиграфическое расчленение. Условные обозначения см. рис. 2.

ПК 3 и ПК 4 из палеогеновой части разреза скв. Алейская 23, и их затруднительно сопоставить с какой-либо конкретной региональной палинозоной Западной Сибири. Здесь отсутствует пыльца Normapolles, которая типична для датско-зеландских комплексов, при этом доля трехбороздно-поровой пыльцы в этих спектрах еще невелика и не отмечены таксоны верхнего эоцена. Возраст вмещающих отложений, предположительно, можно ограничить концом позднего палеоцена-ранним эоценом. Состав и структура спорово-пыльцевых спектров, отсутствие в них морского микрофитопланктона говорят о том, что в скв. Алейская 19, так же как и в скв. Алейская 23, верхнемеловые отложения перекрыты континентальной островновской свитой, и оснований для выделения талицкой свиты (Гнибиденко и др., 2017) нет.

\section{ЗАКЛЮЧЕНИЕ}

Сложное строение мел-палеоген-неогеновых отложений на территории Алтайского края, пространственное распространение и взаимоотношения местных литостратонов, неоднозначное понимание границ и объемов свит, их генезиса вызывают многочисленные вопросы, решить которые можно только детальными исследованиями существующего немногочисленного фактического материала.
Палинологическое изучение верхнемеловых и кайнозойских толщ, вскрытых скв. 23 и 19 Алейской площади, позволили обосновать возраст отложений, высказать предположения об условиях их осадконакопления, уточнить расчленение разреза на свиты.

В меловой части разреза скв. Алейская 23 установлены две пачки с палинокомплексами. Слои с ПК 1 Schizaeaceae, Taurocusporites reduncus, Tricolpites характеризуют леньковскую свиту и датируются сеноманом-туроном. Слои с ПК 2 Aquilapollenites, Oculopollis, Myricaceae/ Betulaceae относятся к верхнесымской подсвите, которая по сопоставлению с фаунистически охарактеризованной ганькинской свитой в настоящее время датируется маастрихтом, маастрихтом-данием. Слои с этим комплексом прослежены также в скв. Алейская 19.

В изученных скважинах не выявлены отложения датско-зеландского возраста, что исключает присутствие здесь талицкой свиты. Верхнемеловые отложения перекрываются континентальной островновской свитой. В разрезе скв. Алейская 19 установлены спорово-пыльцевые спектры, предположительно, позднепалеоценового-раннеэоценового возраста, а в скв. 23 - среднеэоценового возраста. Палеогеновые палинокомплексы в скв. Алейская 23 имеют свои особенности, отличающие их от одновозрастных комплексов в дру- 
гих районах Западно-Сибирской равнины. Так, для ПК 3 характерна значительная доля пыльцы Liquidambar. По-видимому, в первой половине среднего эоцена в данном районе Liquidambar был обычным компонентом ландшафта, занимавшим низинные, подтопляемые равнины, прилегавшие к бассейну седиментации. Выявленный в ПК 4 максимум пыльцы Loranthus коррелируется с увеличением доли кверкоидной пыльцы. Кустарник Loranthus мог паразитировать на древесной растительности, предпочитая дубы.

Несмотря на тщательные микропалеонтологические исследования 50 образцов из скв. Алейская 23, фораминиферы обнаружены не были, что связано с континентальным генезисом отложений. Все это, наряду с литологической характеристикой пород, подтверждает сделанные еще 1960-х годах выводы предшествующих исследований об озерно-аллювиальном и делювиально-пролювиальном генезисе леньковской свиты, озерном генезисе верхнесымской подсвиты, аллювиальном и озерно-болотном генезисе островновской свиты и полностью опровергает сделанные В.М. Подобиной и др. (2011) выводы о морском происхождении меловых и палеогеновых отложений, вскрытых скважинами 19 и 23.

Благодарности. Авторы приносят благодарность В.А. Захарову, М.А. Ахметьеву и А.И. Яковлевой за ценные замечания и комментарии, послужившие улучшению качества статьи.

Источники финансирования. Работа выполнена при поддержке проекта ФНИ № 03312019-0004.

\section{СПИСОК ЛИТЕРАТУРЫ}

Адаменко O.M. Мезозой и кайнозой Степного Алтая. Новосибирск: Наука, 1974. 168 с.

Адаменко О.М. Предалтайская впадина и проблемы формирования предгорных опусканий. Новосибирск: Наука, 1976. $183 \mathrm{c}$.

Амон Э.О., Васильева О.Н., Железко В.И. Стратиграфия талицкого горизонта (палеоцен) в Среднем Зауралье // Стратиграфия. Геол. корреляция. 2003. Т. 11. № 3. C. 92-107.

Ахметьев М.А., Александрова Г.Н., Беньямовский В.Н., Витухин Д.И., Глезер З.И., Гнибиденко З.Н., Дергачев В.Д., Доля Ж.А., Запорожеи, Н.И., Козлова Г.Э., Кулькова И.А., Николаева И.А., Овечкина М.Н., Радионова Э.П., Стрельникова Н.И. Новые данные по морскому палеогену юга ЗападноСибирской плиты. Статья 2 // Стратиграфия. Геол. корреляция. 2004. Т. 12. № 5. С. 65-86.

Бакиева Л.Б. Палинологическая характеристика палеоцена севера Западно-Сибирской плиты //
Стратиграфия. Геол. корреляция. 2003. Т. 11. № 5. C. $58-71$.

Бляхарчук Т.А. Послеледниковая динамика растительного покрова Западно-Сибирской равнины и Алтае-Саянской горной области (по данным спорово-пыльцевого анализа болотных и озерных отложений). Автореф. дисс. ... докт. биол. наук. Томск, $2010.43 \mathrm{c}$.

Васильева O.H. Палинология и стратиграфия морских отложений палеогена Южного Зауралья. Препринт. Свердловск: Изд-во УрО РАН, 1990. 55 с.

Васильева О.Н. Диноцисты палеоцена из отложений талицкой свиты Зауралья // Ежегодник-2002. Информационный сборник научных трудов. Екатеринбург: УрО РАН, 2003. С. 20-30.

Верхнемеловые отложения Южного Зауралья (район верхнего Притоболья). Свердловск: Изд-во УрО АН СССР, 1990. $223 \mathrm{c}$.

Гнибиденко 3.Н., Левичева А.В., Семаков Н.Н., Русанов Г.Г. Палеомагнетизм и магнитостратиграфия верхнемеловых и пограничных мел-палеогеновых отложений юга Кулундинской впадины (Западная Сибирь) // Геология и геофизика. 2017. Т. 58. № 1. C. $105-117$.

Григорьева К.Н. К вопросу о возрасте верхнесымской свиты по данным спорово-пыльцевого анализа // Труды СНИИГГиМС. 1965. Вып. 34. С. 156-168.

Гусев Н.И., Вовшин Ю.Е., Круглова А.А., Пушкин М.Г., Николаева Л.С., Русанов Г.Г., Плеханов О.А., Богомолов В.П., Строев Т.С., Морева Н.В., Сергеева Л.Ю. Государственная геологическая карта Российской Федерации масштаба $1: 1000000$ (третье поколение). Серия Алтае-Саянская. Лист М-44. Рубцовск. Объяснительная записка. СПб.: Картографическая фабрика ВСЕГЕИ, 2015. 415 с.

Зальиман И.Г. Стратиграфия палеогеновых и неогеновых отложений Кулундинской степи. Красноярск: Красноярское книжное изд-во, 1968. 150 с.

Ковалева А.Ф. Верхнемеловые спорово-пыльцевые комплексы Чулымо-Енисейской депрессии. Автореф. дисс. ... канд. геол.-мин. наук. Новосибирск, 1953. $13 \mathrm{c}$

Лебедева Н.К., Зверев К.В. Седиментологический и палинологический анализ сеноман-туронского события на севере Сибири // Геология и геофизика. 2003. T. 44. № 8. C. 769-780.

Лебедева Н.К., Кузьмина О.Б. Палиностратиграфия верхнемеловых и палеогеновых отложений юга Западной Сибири на примере скважин Русско-Полянского района, Омский прогиб // Стратиграфия. Геол. корреляция. 2018. Т. 26. № 1. С. 85-114.

Лебедева Н.К., Александрова Г.Н., Шурыгин Б.Н., Овечкина Н.М., Гнибиденко З.Н. Палеонтологическая и магнитостратиграфическая характеристика верхнемеловых отложений, вскрытых скважиной 8 Русско-Полянского района (юг Западной Сибири) // Стратиграфия. Геол. корреляция. 2013. № 1. C. $1-31$.

Лебедева Н.К., Кузьмина О.Б., Соболев Е.С., Хазина И.В. Новые данные по стратиграфии верхнеме- 
ловых и кайнозойских отложений Бакчарского железорудного месторождения (юг Западной Сибири) // Стратиграфия. Геол. корреляция. 2017. Т. 25. № 1. C. 62-84.

Маркова Л.Г., Широкова Ю.Ф. Спорово-пыльцевые комплексы маастрихтских отложений Тымской скважины 1-P // Геология и геофизика. 1960. № 12. C. $120-123$.

Микрофитофоссилии и стратиграфия мезозоя и кайнозоя Сибири. Ред. Волкова В.С., Хлонова А.Ф., Кулькова И.А. и др. Новосибирск: Наука, 1988. 216 с.

Микрофитофоссилии и детальная стратиграфия морского мезозоя и кайнозоя Сибири. Ред. Ильина В.И., Кулькова И.А., Лебедева Н.К. Новосибирск: Изд-во ОИГГМ СО РАН, 1994. 190 с.

Новиков И.С. Морфотектоника Алтая. Научн. ред. Девяткин Е.В., Уфимцев Г.Ф. Новосибирск: Изд-во СО РАН, филиал “Гео”, 2004. 313 с.

Основы палеонтологии. Членистоногие, трилобитообразные и ракообразные. М.: ГОНТИ, 1960. 515 с.

Подобина В.М., Бабенко С.М., Ксенева Т.Г. Микропалеонтологические комплексы и биостратиграфия верхнего мела-палеогена юго-востока Западной Сибири // Вестник Томск. ун-та. 2011. Вып. 347. С. 191203.

Практическая палиностратиграфия. Ред. Панова Л.А., Ошуркова М.В., Романовская Г.М. Л.: Недра, 1990. $348 \mathrm{c}$.

Пыльца и споры Западной Сибири (юра-палеоцен). Л.: Гостоптехиздат нефтяной и горно-топливной литературы, 1961. 352 с. (Труды ВНИГРИ. Вып. 177).

Решение 5-го Межведомственного регионального стратиграфического совещания по мезозойским отложениям Западно-Сибирской равнины. Тюмень: ЗапСибНИГНИ, 1991. 54 с.

Русанов Г.Г. Западные предгорья Алтая в мезозое и кайнозое. Бийск: Бийский педагогический гос. ун-т, 2009. 142 c.

Cтрепетилова В.Г. Новые данные палинологических исследований сеноман-туронских отложений Западно-Сибирской равнины // Вопросы биостратиграфии и детальной корреляции мезозойских и кайнозойских отложений Западно-Сибирской равнины. Тюмень: ЗапСибНИГНИ, 1979а. С. 62-63.

Cmpenemилова В.Г. Новые виды спор родов Ruminatisporites и Carnisporites из сеноман-туронских отложений Западной Сибири // Вопросы биостратиграфии и детальной корреляции мезозойских и кайнозойских отложений Западно-Сибирской равнины. Тюмень: ЗапСибНИГНИ, 1979б. С. 8-12.

Cmpenетилова В.Г. Биостратиграфия апт-туронских отложений Надым-Тазовского междуречья // Пали- нологические исследования мезозоя и кайнозоя Западной Сибири. Вып. 149. Тюмень: ЗапСибНИГНИ, 1980. С. 103-109.

Cmрепетилова В.Г. Особенности спорово-пыльцевых комплексов на границе раннего-позднего мела // Биостратиграфия осадочного чехла ЗападноСибирской равнины. Тюмень: ЗапСибНИГНИ, 1989. C. 107-115.

Терещенко P.A., Зинова Р.A. Палинологическая характеристика и соотношение разрезов павлодарской и кедейской свит раннего плиоцена на севере Центрального Казахстана // Палинологические исследования в Казахстане. Алма-Ата: КазИМС, 1981. С. 74-82.

Унифицированные региональные стратиграфические схемы палеогеновых и неогеновых отложений Западно-Сибирской равнины. Объяснительная записка и схема. Новосибирск: Изд-во СНИИГГиМС, 2001.84 c.

Хлонова А.Ф. О выделении руководящих видов при определении возраста отложений по спорово-пыльцевому анализу // Изв. Восточных филиалов АН СССР. 1957. № 2. С. 43-46.

Хлонова А.Ф. Видовой состав пыльцы и спор в отложениях верхнего мела Чулымо-Енисейской впадины. Новосибирск: Изд-во СО АН СССР, 1960. 104 с.

Хлонова А.Ф. Споры и пыльца верхней половины верхнего мела восточной части Западно-Сибирской низменности. Новосибирск: Изд-во СО АН СССР, $1961.138 \mathrm{c}$.

Хлонова А.Ф. Палинология меловых отложений Сибири и Дальнего Востока. Новосибирск: Наука, 1974. $166 \mathrm{c}$.

Хлонова $A . \Phi$. Палинологическая характеристика отложений маковской свиты в Туруханской скважине I-P // Микрофитофоссилии и стратиграфия мезозоя и кайнозоя Сибири. Новосибирск: Наука, 1988. C. $18-25$.

Яковлева А.И., Александрова Г.Н. К вопросу об уточнении зонального деления по диноцистам палеоцен-эоценовых отложений Западной Сибири // Бюлл. Моск. о-ва испытателей природы. Отд. геол. 2013. T. 88. № 1. C. 59-81.

Iakovleva A.I., Kulkova I.A. Paleocene-Eocene dinoflagellate cysts and continental palynomorphs of the Pur Downstream Basin (Northwestern Siberia): biostratigraphical and palaeoenvironmental implications // Revista Española de Micropaleontologia. 2001. V. 33. № 1. P. $1-31$.

Magri D., Di Rita F., Aranbarri J., Fletcher W., Gonzalez-Samperiz P. Quaternary disappearance of tree taxa from Southern Europe: timing and trends // Quaternary Sci. Rev. 2017. V. 163. P. 23-55.

Рецензенты М.А. Ахметьев, В.А. Захаров, А.И. Яковлева 


\title{
PALYNOSTRATIGRAPHY AND GENESIS OF UPPER CRETACEOUS AND CENOZOIC DEPOSITS IN THE SOUTHERN PART OF THE KULUNDA DEPRESSION, ALTAI REGION
}

\author{
N. K. Lebedeva ${ }^{\text {a, b}}$, O. B. Kuzmina ${ }^{\text {a, b}}$, I. V. Khazina ${ }^{a}$, \\ G. G. Rusanov ${ }^{\mathrm{c}}$, L.A. Glinskikh ${ }^{\text {a, b }}$ \\ ${ }^{a}$ Trofimuk Institute of Petroleum Geology and Geophysics SB RAS, Novosibirsk, Russia \\ ${ }^{b}$ Novosibirsk State University, Novosibirsk, Russia \\ ${ }^{c}$ Gorno-Altaian expedition, Maloeniseiskoye Village, Bijsk Region, Altay Territory, Russia
}

The results of palynological and micropaleontological study of Upper Cretaceous-Cenozoic strata exposed by boreholes (BH) 23 and 19 of the Aleisk Square (Altai Region) are presented. The obtained data allowed to substantiate the age of deposits, to make assumption about its depositional conditions and to clarify the division of the section into suites. Two palynological assemblages were established in the Cretaceous part of the BH 23 section: the first characterizes the Len'ki Formation and dates by SenomanianTuronian, the second one is revealed in the Upper-Sym Subformation and dates by the Maastrichtian. The Paleogene Ostrovnoye Formation of continental genesis lies on the Upper Cretaceous sediments. In BH 23 and $\mathrm{BH}$ 19, this formation contains spore and pollen spectra of presumably Late PaleoceneEarly Eocene and Middle Eocene age respectively. According to palynological data, the Late Miocene age of the sediments at the upper part of BH 23 section and its affiliation to Pavlodar Formation have been substantiated. The structure of palynological assemblages, features of macerate and the absence of foraminifera indicate the continental genesis of the Upper Cretaceous-Paleogene sediments common in the southern part of the Kulunda Depression of the Altai Region.

Keywords: biostratigraphy, Upper Cretaceous, Paleogene, Neogene, Kulunda Depression, South of Western Siberia, Altai Region, palynology, terrestrial palynomorphs.

DOI: https://doi.org/10.31857/S0869-592X27655-77 